\title{
The effect of CEO incentives on deviations from institutional norms in foreign market expansion decisions: Behavioral agency and cross-border acquisitions
}

\author{
Mirko H. Benischke ${ }^{1}$ | Geoffrey P. Martin ${ }^{2}$ () | Luis R. Gomez-Mejia ${ }^{3}$ | \\ Grigorij Ljubownikow ${ }^{4}$
}

\author{
${ }^{1}$ Department of Strategic Management and \\ Entrepreneurship, Erasmus University, \\ Rotterdam School of Management, Rotterdam, \\ The Netherlands \\ ${ }^{2}$ Department of Business Administration, \\ University of Melbourne, Melbourne Business \\ School, Melbourne, Victoria, Australia \\ ${ }^{3}$ W.P. Carey School of Business, Arizona State \\ University, Tempe, Arizona \\ ${ }^{4}$ Department of Management and \\ International Business, University of Auckland \\ Business School, Auckland, New Zealand \\ Correspondence \\ Mirko H. Benischke, Erasmus University, \\ Rotterdam School of Management, \\ Department of Strategic Management and \\ Entrepreneurship, Burgemeester Oudlaan 50, \\ Rotterdam 3042 NA, The Netherlands. \\ Email: benischke@rsm.nl
}

\begin{abstract}
CEO incentives have been the subject of great interest for human resource scholars. We explore the institutional context within which the CEO makes sense of their incentives. Our theory suggests that CEO equity incentives interact with institutional norms to influence foreign market entry choices. Specifically, we argue that CEOs will weigh the risk bearing created by equity incentives, along with the consequences of legitimacy loss, when deciding whether to deviate from institutional norms when internationalizing. In doing so, we advance human resource literature by demonstrating that CEO responses to incentives are influenced by institutional norms and that CEOs' decisions to deviate from institutional norms are shaped by their incentives. We find support for our framework in the analysis of the stake taken by acquirers in 4,184 cross-border acquisitions.
\end{abstract}

KEYWORDS

agency theory, CEO compensation, compensation and benefits, institutional theory

\section{INTRODUCTION}

Human resource management (HRM) professionals and academics have long been interested in understanding the effect of CEO incentives on firm behaviors (e.g., Aguinis, Martin, Gomez-Mejia, Boyle, \& Joo, 2018; Benischke, Martin, \& Glaser, 2019; Bragaw \& Misangyi, 2017; Seo, 2017; Sung, Choi, \& Kang, 2017; Wang \& Singh, 2014; Werner \& Ward, 2004). Within this body of research, an increasing number of human resource scholars have explored the relationship between CEO incentives and multinational corporations (MNCs) foreign market expansion decisions (e.g., Datta, Musteen, \& Herrmann, 2009; Gomez-Mejia \& Welbourne, 1991; Jaw \& Lin, 2009; Levy, 2005; Su, Fan, \& Rao-Nicholson, 2017). For example, Musteen, Datta, and Herrmann (2009) show that CEOs are more likely to select full-control entry modes as the proportion of their compensation that is tied to firm long-term performance increases. Similarly, Woo (2019) finds that CEO equity-based compensation is positively related to the likelihood that new ventures internationalize early. The view that has emerged from this literature is that internationalization decisions can be explained by CEO incentives that are designed by the board and HRM professionals (Gomez-Mejia \& Wiseman, 2007; Gomez-Mejia, Wiseman, \& Johnson, 2005).

Although this stream of research has produced important insights, little is known about how the embeddedness of the CEO in a particular social or institutional context influence foreign market expansion decisions in response to incentives. In fact, the literature on the effect of CEO incentives on MNC internationalization decisions has developed almost independently from a large body of research that considers how institutional forces influence MNCs' foreign market entry mode decisions (e.g., Salomon \& Wu, 2012; Yiu \& Makino, 2002). Specifically, while HRM scholars have primarily focused on studying how CEO incentives influence the choice between, for example, full control or shared control entry modes (e.g., Musteen et al., 2009), institutional scholars have shown that MNCs often succumb to host country institutional pressures when expanding abroad (e.g., Ang, Benischke, \& Doh, 2015; Lu, 2002). This has resulted in an incomplete understanding of 
how CEO incentive structures influence MNCs' internationalization strategies. An important yet unanswered question is: Do CEO incentives influence how the firm responds to institutional pressure in foreign market entry mode decisions? This question is all the more critical considering that prior research has started to document that MNCs do, in fact, increasingly deviate from local norms; but we lack insight into why deviations arise (e.g., Regner \& Edman, 2014).

In this study, we seek to address the aforementioned question by combining insights from institutional theory in its sociological form (DiMaggio \& Powell, 1983) and the most recent HRM literature exploring CEO incentives using behavioral agency literature (e.g., Martin Washburn, Makri, \& Gomez-Mejia, 2015; Martin, Wiseman, \& GomezMejia, 2016; Zolotoy, O'Sullivan, Martin, \& Veeraraghavan, 2018). In particular, we argue that equity incentives influence CEO responses to institutional pressures in MNCs foreign market expansion decisions; yet that these incentives are not always consistent with institutional conformance pressures. Our guiding premise is based on predictions from the behavioral agency model (BAM; Denya, Gomez-Mejia, DeCastro, \& Wiseman, 2005; Wiseman \& Gomez-Mejia, 1998), suggesting that loss averse CEOs take less risk as they accumulate equity wealth. In the context of our study, this insight suggests that CEOs weigh the potential losses of current personal wealth when making foreign market entry mode decisions, suppressing the perceived need to conform to institutional norms. In other words, we propose that CEOs' concern for the preservation of equity wealth can make them less likely to conform to local institutional norms, and this influences their foreign expansion decisions.

We test our hypotheses by analyzing the impact of CEO incentives on decisions regarding equity ownership alternatives in crossborder acquisitions. This context allows us to operationalize institutional pressures and observe CEO responses to both institutional pressure (Chan \& Makino, 2007) and their incentives. As such, our empirical context also connects with a stream of HRM research exploring the role of CEO incentives in acquisition activities (Rich \& Bush, 1987), including cross-border acquisition integration challenges (Bagdadli, Hayton, \& Perfido, 2014; Khan, Rao-Nicholson, Akhtar, \& $\mathrm{He}$, in press) and implications of cross-border acquisitions for HRM systems (e.g., Cooke \& Huang, 2011; Yahiaoui, Chebbi, \& Weber, 2016).

Based on the analysis of 4,184 cross-border acquisitions, we find general support for the prediction that foreign market entry decisions result from a combination of both CEO incentives and institutional norms. The literature on compensation strategy goes back a few decades (e.g., Balkin \& Gomez-Mejia, 1987, 1990; Gomez-Mejia, 1992; Gomez-Mejia, McCann, \& Page, 1985), yet most of this research has circumvented the issue of foreign expansion decisions in response to institutional pressures and the focus has generally been restricted to the effect of CEO incentives on the choice between a given set of entry modes. Our study shifts the theoretical focus to studying how CEO incentives influence MNC's conformance strategies. Specifically, our study suggests that CEO incentives can lead to less institutional conformity when MNCs are expanding abroad. This perspective not only contrasts prior findings that CEO incentives may reinforce existing institutional norms (Berrone \& Gomez-Mejia, 2009) but also draws attention to an interesting decision-making dilemma to which HRM researchers have paid limited attention: under which conditions are CEOs willing to trade personal benefits for firm-level legitimacy gains? By doing so, our study also adds a new dimension to the emerging stream of literature (e.g., Rathert, 2016; Regner \& Edman, 2014; Tsui \& Moellering, 2010) that seeks to explain heterogeneous MNC responses to institutional pressures-instead of conformance strategies-by introducing a CEO-centric (HRM) explanation of deviations from the norm.

\section{2 | THEORETICAL BACKGROUND AND HYPOTHESES}

The role of the CEO has long been of interest to HRM professionals and academics (e.g., Gomez-Mejia, 1994; Gomez-Mejia, Tosi, \& Hinkin, 1987; Gomez-Mejia \& Wiseman, 2007; Patel, Li, Triana, \& Park, 2018). Within this literature, two dominant research streams can be identified (Koyuncu, Hamori, \& Baruch, 2017; Wang, Holmes, Oh, \& Zhu, 2016). One set of literature has focused on the effect of CEO demographic characteristics on firm outcomes, including internationalization decisions. These studies are mainly grounded in upper echelons theory (Hambrick \& Mason, 1984) and argue that CEO characteristics direct the attention, selection and interpretation of environmental stimuli which should in return be reflected in the firm's internationalization decisions (e.g., Benson, Perez-Nordtvedt, \& Datta, 2009; Herrmann \& Datta, 2006; Isidor, Schwens, \& Kabst, 2011; Jaw \& Lin, 2009; Kunisch, Menz, \& Cannella Jr., 2019; Le \& Kroll, 2017; Su et al., 2017). Another stream in the HRM literature has examined how CEO incentives influence internationalization decisions. Most of these studies adopt an agency perspective, suggesting that CEO incentives can explain strategic risk taking behavior-and therefore firm internationalization decisions (e.g., Gomez-Mejia, 1988; Musteen et al., 2009; Sanders \& Carpenter, 1998; Woo, 2019). In particular, these studies tend to argue that increases in equity compensation align the CEO's risk preference with those of shareholders, resulting in the adoption of higher risk entry modes (e.g., Hou, Li, \& Priem, 2013; Musteen et al., 2009).

Yet, while prior HRM literature has clearly demonstrated the important role of CEO incentives in influencing firms' strategic choices, including foreign market expansion strategies, most of these studies have paid limited attention to the social or institutional context in which these decisions are made (Zolotoy et al., 2018). This is, among others, reflected in the dominant approach in prior HRM literature to link CEO incentives to the choice between a given set of foreign market entry modes (e.g., Musteen et al., 2009). This approach, however, is problematic because prior research studying MNC strategy through an institutional lens has documented the influence of institutional pressures on MNCs' internationalization strategies. For example, Yiu and Makino (2002) show that host country institutions influence MNCs' entry mode decision (see also Ang et al., 2015; Powell \& Rhee, 2016; Xia, Tan, \& Tan, 2008). In this regard, institutional scholars 
emphasize MNCs need to adopt strategies that are "taken-for-granted" and thus acceptable within a particular institutional field (Zimmerman \& Zeitz, 2002; Zucker, 1977). Deviations from these institutionally prescribed action patterns (non-conformity) are punished with the loss of legitimacy (e.g., Grossman \& Schoenfeld, 2001).

While this stream of research suggests that CEOs should indeed have an interest to adopt conformance strategies when expanding abroad, there is strong evidence showing that MNCs increasingly deviate from host country norms (e.g., Bae, Chen, \& Lawler, 1998; Cantwell, Dunning, \& Lundan, 2010; Faulconbridge \& Muzio, 2016; Holm, Decreton, Nell, \& Klopf, 2017; Regner \& Edman, 2014). One possible explanation for this observation-one that has also implicitly been acknowledged by neoinstitutional theorists (Meyer \& Rowan, 1977)-is that while the pursuit of isomorphic (or conformance) strategies may indeed reduce legitimacy risk, such strategies may at the same time increase firm-specific business risk. ${ }^{1}$ That is, while we do not assume that legitimacy and business risk are always asymmetrical, previous work documents that CEOs are often confronted with decision-situations in which legitimacy risk reduction may be achieved at the expense of an increase in business risk; hence, they must manage the tension between legitimacy and business risk (Barreto \& Baden-Fuller, 2006; Chung \& Luo, 2013; Meyer \& Rowan, 1977; Reusen \& Stouthuysen, 2017; Westphal, Gulati, \& Shortell, 1997).

Legitimacy risk reduction may increase firm-specific business risk for various reasons. First, the adoption of isomorphic strategies can have a negative impact on firm performance as firms pursuing isomorphic strategies may forego opportunities that are more lucrative (Barreto \& Baden-Fuller, 2006). Second, the pursuit of isomorphic strategies in response to institutional pressures could engender business risks because firms may adopt strategies that are incompatible with current organizational structures or culture (Reusen \& Stouthuysen, 2017; Westphal et al., 1997). Third, conformity may pose a threat to a firm's financial performance if the strategy adopted in response to institutional pressures is an inherently higher risk than the alternatives (Barreto \& Baden-Fuller, 2006). Forth, once an isomorphic strategy is adopted, this constrains the exploration of other alternatives due to the consumption of specific resources (sunk costs) involved; the magnitude and specificity of the resource commitment to an isomorphic path makes it difficult to reallocate or replace those resources in the future to pursue practice variation. This can expose the firm to greater business risk if it limits its adaptive capability or the discretion to respond to emerging environmental opportunities.

HRM scholars studying the effect of CEO incentives on MNCs foreign expansion strategies, however, have largely neglected the notion that CEOs may be confronted with situations in which legitimacy risk reduction may be achieved at the expense of an increase in business risk. While this omission is not surprising given that those literatures have evolved independently from each other, the persistence of this gap results in an incomplete picture of the effect of CEO incentives on MNCs foreign market entry mode decisions. Specifically, previous work tends to neglect that conformance decisions when expanding abroad also have implications for CEO equity wealth. However, given the inter-relationship between CEO firm-specific equity wealth and firm share price performance (Nyberg, Fulmer, Gerhart, \& Carpenter, 2010), there is the possibility that the magnitude to which legitimacy reduction threatens the CEO's firm-specific equity wealth (through an increase in business risk) may determine their willingness to conform to host country institutional pressures. In other words, integrating insights from the HRM literature on the effect of CEO incentives on MNC strategy and research studying MNC strategy through an institutional lens, an important yet unanswered question emerges: What is the effect of CEO incentives on their responses to institutional host country pressures? In order to address this question, we next review BAM and institutional literature.

\subsection{BAM and responses to institutional pressures}

BAM infused traditional agency theory with the findings derived from behavioral decision research with the objective of improving our ability to predict the risk taking behavior of managerial agents (Gomez-Mejia, Larraza-Kintana Moyano, \& Firfiray, 2017; Gomez-Mejia, Welbourne, \& Wiseman, 2000; Wiseman \& Gomez-Mejia, 1998). For instance, BAM replaced agency theory's assumption of a managerial agent that is risk averse with the assumption that the agent is loss averse. This derives from prospect theory's concept of loss aversion, based on the insight that individuals will avoid risk when faced with a certain gain (risk aversion), yet they will take additional risk in order to avoid impending losses to endowed wealth (risk seeking) (Kahneman \& Tversky, 1979). Moreover, BAM suggests that the CEO's perceived wealth-at-risk (or risk bearing) mediates the influence of CEO loss aversion upon risk taking, leading to the prediction that CEO risk bearing and risk taking are negatively related (Wiseman \& Gomez-Mejia, 1998). Behavioral agency research has also increasingly been leveraged in the HRM literature to explain CEO manipulation of firm business risk (using strategic levers: Benischke et al., 2019; Gomez-Mejia, Neacsu, \& Martin, 2019; Martin, Gomez-Mejia, \& Wiseman, 2013, Martin et al., 2015; Zolotoy et al., 2018) to limit risk of personal wealth loss; yet this research has not considered the legitimacy risks associated with strategic decisions. Below, we integrate behavioral agency with institutional theory to examine how the CEO is likely to respond to business risk when making decisions in response to institutional pressure.

\subsection{1 | CEO incentives and institutional conformance}

Neoinstitutional theory is built on the notion that firms will succumb to institutional pressures to increase legitimacy (Meyer \& Rowan, 1977). As noted above, a reduction of firm-level legitimacy risk through enhancing legitimacy, however, may in some situations be hindered by an increase in business risk that could negate the net firm risk reduction that the CEO would achieve through institutional conformance. Hence, the CEO may have to consider the business risk of 
conformance when assessing the consequences of conformance for their personal wealth (Merriman \& Deckop, 2007). Specifically, in the context of this study, we argue that acquiring an equity stake in crossborder acquisitions similar to those acquired by prior market entrants (i.e., lower deviation from the industry norm) due to institutional pressures increases business risk for several reasons. ${ }^{2}$

First, firms that conform to institutional pressures when deciding upon the equity stake in a target, may be confronted with greater acquisition costs given the greater sunk costs associated with such deals (Slangen, 2013). Thus, in the context of cross-border acquisition strategies, if institutional pressures require the acquirer to take a given equity stake in the local target, the reduction of legitimacy risk often comes with higher business risk for the firm due to higher sunk costs that cannot easily be recovered. Second, firms that conform to institutional pressures when deciding upon the equity stake in a target, are also at a greater risk of misevaluation, and specifically, overvaluation of the target firm (e.g., Rhodes-Kropf, Robinson, \& Viswanathan, 2005), resulting in a lower likelihood that synergies can be achieved. This argument is consistent with the notion that high institutional pressures lead the remaining firms to "collectively bid up the prices of the remaining targets" (McNamara, Haleblian, \& Dykes, 2008, p. 116). Lastly, while some of the factors determining the optimal equity stake are country- or industry-specific, idiosyncratic firm-level characteristics have been shown to be particularly consequential (Slangen \& Hennart, 2007). Therefore, in any given host country, the optimal equity stake in a target in cross-border acquisitions differs across MNCs, depending on firm-level factors such as international experience and R\&D intensity (Zhao, Luo, \& Suh, 2004). Conformance decisions can, therefore, create performance risk because these conformance decisions are primarily based on external institutional forces, thereby often resulting in suboptimal equity stake decisions that may not be best suited to exploit idiosyncratic firm-specific advantages (Harzing, 2002).

As suggested by prior HRM literature (e.g., Brandes, Dharwadkar, \& Das, 2005), CEOs are likely to consider the legitimacy and business risks associated with cross-border acquisitions when considering the threat that these transactions may create to their firm. Hence, when legitimacy is earned through acquiring an equity stake in the foreign target that does not deviate from the industry norm, and this legitimacy (or reduction in legitimacy risk) can increase business risk (GomezMejia \& Palich, 1997; Palich \& Gomez-Mejia, 1999), CEOs have a dilemma. The CEO can decide to: (a) reduce legitimacy risk through taking the equity stake demanded by institutional norms (low deviation from the industry norm), or to (b) reduce business risk through deviating from the norm by taking a different equity stake in the foreign target than the industry norm. Given BAM suggests that CEOs with greater risk bearing will avoid strategic decisions that jeopardize their firmspecific equity wealth, we suggest that the CEO's level of risk bearing (equity wealth-at-risk of loss) will determine the degree to which they are willing to deviate from the industry norm when deciding upon the equity stake taken in a foreign target. Specifically, we expect that, despite potential firm-level legitimacy benefits, CEOs with greater levels of risk bearing tend to avoid increasing business risk and, hence, are more likely to deviate from the industry norm. This is because increases in business risk translate into a greater personal risk of loss for those CEOs whose personal wealth is tied to the performance of the focal firm through equity grants (Wiseman \& Gomez-Mejia, 1998). Said differently, accepting greater business risk in return for a legitimacy risk reduction also increases the personal risk of loss for the CEO as their equity risk bearing increases. ${ }^{3}$

In sum, because CEOs with greater levels of risk bearing are more likely to be motivated to reduce firm risk to preserve that wealth (Benischke et al., 2019; Martin et al., 2013; Martin et al., 2015) they should be less prone to conform to institutional pressures that increase business risk despite the possibility of legitimacy gains. This leads to our prediction that CEOs are more likely to deviate from the industry norm (such as the equity stake taken in cross-border acquisitions by prior acquirers) as their equity wealth (equity risk bearing) increases.

Hypothesis 1 CEO equity risk bearing will increase the deviation from the industry norm when deciding on the equity stake taken in a foreign target.

So far, we have assumed that CEOs have full discretion over the degree of legitimacy risk they are willing to accept in exchange for a reduction in business risk. However, in its original formulation, institutional theory leaves little room for such managerial discretion (DiMaggio \& Powell, 1983). While subsequent work has relaxed this notion (Cantwell et al., 2010; Regner \& Edman, 2014), there is most likely variation in the degree to which CEOs have discretion to deviate from the norm when deciding upon the equity stake taken in a foreign target. Here, we focus on two particularly important host country characteristics that may influence CEOs ability to deviate from the norm in order to reduce business risk when expanding abroad through cross-border acquisitions: host country governance quality and cultural tightness/looseness.

\subsection{2 | Governance quality, CEO risk preferences, and institutional conformance}

Host country governance quality refers to the quality of a given host country's governance infrastructure (Slangen \& van Tulder, 2009), which is defined as a host countries set of "public institutions and policies created by governments as a framework for economic, legal, and social relations" (Globerman \& Shapiro, 2003, p. 20). It includes (a) the process by which governments are selected, monitored, and replaced; (b) the capacity of the government to effectively formulate and implement sound policies; and (c) the respect of citizens and the state for the institutions that govern economic and social interactions among them (Kaufmann, Kraay, \& Mastruzzi, 2010, p. 4).

We argue that in host countries with a higher quality of governance infrastructure, CEO's discretion to deviate from the norm is lower. Said differently, in host countries characterized by high levels of governance quality, there is greater enforcement of institutional 
norms (Waguespack, Dunford, \& Birnir, 2018) and MNCs, therefore, have less opportunity to deviate from the norm without risking severe social penalties (Cantwell et al., 2010). This is because, in host countries characterized by high levels of governance quality, the overall adaptability of the local institutional system is very low. As a result, the local institutional system leaves little room to accommodate strategies that are inconsistent with local norms, thereby creating an environment that highly favors-and enforces-conformance strategies (Westney, 1993). In such a context, MNCs have a strong incentive to achieve a high fit with the local institutional environment and CEOs with high levels of equity risk bearing have thus limited opportunities to reduce business risk in exchange for an increase in legitimacy risk. That is, CEOs with high levels of equity risk bearing should face more difficulties deviating from institutional norms in host countries with stronger governance given expectations of conformity toward foreign MNCs are higher (Regner \& Edman, 2014). Therefore, we hypothesize the following:

Hypothesis 2 The likelihood that increases in CEO equity risk bearing lead to deviations from the industry norm when deciding on the equity stake taken in a foreign target is weaker in host countries with high governance quality.

\subsection{3 | Cultural tightness, CEO risk incentives and institutional conformance}

While governance quality captures the formal aspect of a host country's institutional environment (Ang et al., 2015), the informal element is, in part, reflected in the host country's national culture (GomezMejia, 1984; Gomez-Mejia \& Palich, 1997). National culture has long been postulated as a salient variable in MNCs entry mode decisions including equity stake choices in cross-border acquisitions (Brouthers \& Hennart, 2007; Tihanyi, Griffith, \& Russell, 2005). In this regard, building on related work in anthropology (Pelto, 1968), sociology (Boldt, 1978), and psychology (Berry, 1967; Carpenter, 2000, Gelfand, Nishii, and Raver (2006) introduced the concept of societal tightness/looseness. In contrast to competing frameworks such as the cultural values framework (Hofstede, 1980), the concept of cultural tightness/looseness explicitly considers the influence of societal norms and the degree of sanctioning within societies (Gelfand et al., 2006; Gelfand, Erez, \& Aycan, 2007). While values and norms are often used indiscriminately, the concepts are indeed distinct (Gelfand et al., 2011). Whereas values are located at the individual level, norms are located at the societal level (Leung \& Morris, 2015). To integrate the notion of norms as well as the idea of sanctioning, the conceptual focus is on the distinction between cultures that can be described as "loose" versus those that are considered to be more "tight."

This distinction between loose and tight cultures captures the degree to which societies are characterized by weak (strong) norms and tolerance for deviant behavior from these norms. Building on these ideas, we suggest that in host countries with tight national cultures, foreign MNCs, and their CEOs have less flexibility in the decision to deviate from the norm-even though the CEO may have an incentive to do so due to high equity risk bearing. This is because societies that are considered to be tight (loose) are characterized by strong (weak) norms and relatively low (high) tolerance for deviant behavior. In other words, people in societies characterized by cultural tightness have been socialized in environments that strongly encourage conformance to local norms (Chua, Roth, \& Lemoine, 2014; Toh \& Leonardelli, 2012); those that deviate are often confronted with severe punishments. In support of this conjecture, Gelfand et al. (2006:1236) also reason that strong isomorphic pressures for organizations in tight societies may explain the dominance of homogenous organizational forms. In addition, Crossland and Hambrick (2011) show that in loose cultures, CEOs have more discretion. Thus, even though CEOs with high levels of equity risk bearing may have an incentive to accept greater legitimacy risk in exchange for a reduction in business risk, they may have less opportunity to do so because the social costs of deviation would outweigh potential benefits. We, therefore, propose the following hypothesis:

Hypothesis 3 The likelihood that increases in CEO equity risk bearing lead to deviations from the industry norm when deciding on the equity stake taken in a foreign target is stronger in host countries characterized by tight national cultures.

\section{3 | METHODOLOGY}

Our sample consists of cross-border acquisitions announced by U.S. MNCs from 1993 to 2016. Studying the effect of institutional pressures on the equity stake MNCs are acquiring in foreign target firms is not unprecedented (Chan \& Makino, 2007) and thus provides a suitable context to test our theoretical framework. In fact, prior studies have consistently emphasized that ownership decisions may be a means of conformity to foreign institutional fields (e.g., Ang et al., 2015; Chan \& Makino, 2007; Guillén, 2002). As a starting point, we identified all cross-border acquisitions announced by S\&P 1,500 companies. We focus on the S\&P 1,500 since these firms are also covered in the Execucomp database on which we relied to gather data on CEO compensation. We applied four additional sampling filters. First, we have excluded all cross-border acquisitions by firms in the Finance, Insurance, and Real Estate category (SIC 60-69) because these firms often engage in cross-border acquisitions for non-strategic reasons. Second, we excluded cross-border acquisitions of remaining stakes as our theory is most relevant in explaining initial stakes taken by the acquirer (Chan \& Makino, 2007). Third, we exclude cross-border acquisitions with equity stakes under $10 \%$ equity as these represent portfolio investments in which foreign investors merely acquire equity in a foreign-based firm without effective control or at least meaningful influence over the acquired firm's decision making (United Nations Conference on Trade and Development, 2018). Fourth, we included only completed acquisitions rather than acquisitions that were announced but not completed. Data on acquisitions 
has been collected from SDC Platinum. CEO compensation data has been extracted from Execucomp, and firm-level financial data was collected from COMPUSTAT. After accounting for missing data, our sample consists of 4,184 cross-border acquisitions that have been announced by 1,065 unique firms.

\section{1 | Dependent variable}

The dependent variable in our study is the deviation from the industry norm in the equity stake the U.S.-based MNC acquired in the foreign firm. To measure this variable, we first need to define the industry norm. Drawing on related work in institutional theory, we defined the relevant institutional field at the host country-industry level (Ang et al., 2015). While MNCs may face fragmented institutional fields (Kostova, Roth, \& Dacin, 2008), previous work has demonstrated that MNCs are most likely to respond to pressures emanating from firms within the target host country industry as opposed to the behavior of all firms (Xia et al., 2008). We have therefore focused on other foreign MNCs' equity stake decisions as a reference group (Ang et al., 2015). It is also likely that institutional pressures stemming from the behavior of other firms in the same industry within the same country is strongest for more recent behavior (Baum, Li, \& Usher, 2000). Thus, we measure the industry norm as the average ownership stake taken by other foreign MNCs in the same host country, in the same target firm industry (at the twodigit SIC level), in the 3-year period prior to the transaction (see the endogeneity and robustness tests section for alternative approaches we have considered when defining the industry norm).

Acquiring an equity stake in the foreign target firm that does not deviate from the industry norm is an isomorphic choice to lower legitimacy risk; conversely, acquiring an equity stake in the foreign target firm that deviates from the industry norm is a non-isomorphic choice that increases legitimacy risk. Therefore, we compute our dependent variable, equity stake deviation, as the absolute difference between the industry norm and the equity stake taken by the U.S.-based MNC in the foreign firm.

\section{2 | Independent variable}

\subsection{1 | CEO risk bearing}

To measure the degree to which personal risk to the CEO influences deviations from the industry norm, we focus on CEO equity risk bearing. Consistent with prior research examining CEO firm-specific equity risk bearing (e.g., Benischke et al., 2019; Martin et al., 2013), we use a variable labeled CEO equity that captures the combined cash value of the CEO's exercisable options and unexercisable options to capture equity risk bearing. The cash value of exercisable and unexercisable options is calculated by multiplying the number of options by their corresponding spread (for in-the-money) options at fiscal year-end (Devers, McNamara, Wiseman, \& Arrfelt, 2008; Martin et al., 2013). This variable is measured at $t-1$.

\section{3 $\quad$ Moderating variables}

To test Hypothesis 2 and Hypothesis 3, we need to examine if the deviations from the industry norm are influenced by host country governance and cultural tightness/looseness. Following prior research (e.g., Dikova \& van Witteloostuijn, 2007; Slangen \& van Tulder, 2009), we use the average score of the World Bank's six governance dimensions to measure host country governance quality. As noted above, the World Bank governance indicators consist of six dimensions: voice and accountability, political stability, government effectiveness, regulatory quality, rule of law, and control of corruption (Kaufmann et al., 2010). For each dimension, every country covered in the database receives a score that ranges from -2.5 to 2.5 , with lower (higher) values indicating a lower (higher) governance quality. We use the average score of the six dimensions to calculate a composite measure of host country governance quality. To test Hypothesis 2, we interact this variable with the CEO equity variable.

To measure cultural tightness/looseness, we use the measure developed by Gelfand et al. (2011). This measure captures "the difference between nations that are 'tight'-have strong norms and low tolerance of deviant behavior-and those that are 'loose'-have weak norms and a high tolerance of deviant behavior" (Gelfand et al., 2011, p. 1100). Hence, the tightness score captures the pressure for conformance to social institutional norms in the host country. To do this, we use the tightness score, termed cultural tightness in our study, to measure the social pressure in the host country to comply with equity stake norms. To test Hypothesis 3 , we interact this variable with the CEO equity variable.

\subsection{Control variables}

In order to rule out alternative explanations, we control for a number of variables at the country, firm, transaction, and CEO level that can affect the stake taken by acquirers in cross-border acquisitions. We control for the size of each host market through host country GDP and the level of economic development of each host market through host country GDP per capita (e.g., Slangen, 2013). Given our research context, it is also important to control for the existence of investment restrictions. Consistent with prior studies (e.g., Slangen, 2013) we control for elements of the political host country institutional environment not covered by our moderating variable using two different variables. First, we control for investment restrictions. This variable is based on survey data included in IMD's World Competitiveness Yearbook. Specifically, we include the average responses to the statement "Foreign investors are free to acquire control in domestic companies." This variable can take a value from 0 to 10 , whereby a higher value indicates fewer investment restrictions. We thus reverse coded this variable to capture the degree to which foreign investors face investment restrictions. Second, we use the Political Constraint Index (Henisz, 2000) to control for host country political risk. This variable can take any value between 0 and 1 , whereby a higher value indicates less political risk. We thus reverse coded this variable in order to 
capture the degree to which foreign investors face political risks. We further control for geographic distance, measured as the great-circle distance in kilometers between the capital cities of the home and host countries.

We also control for elements of the social host country institutional environment not covered by our moderating variable using two different variables. First, we control for cultural distance. Our measure of cultural distance is based on Hofstede's (1980) cultural dimensions and the Kogut and Singh (1988) formula to calculate our cultural distance measure. Second, we control for whether or not the target nation has a common official language with the acquirer nation using a dummy variable that takes the value of 1 if both nations share an official language, and zero if otherwise.

At the transaction level, we include a dummy variable controlling for the relatedness of the transaction. Diversification is coded as one if the acquisition target firm comes from a different SIC-2 industry, and zero if otherwise. We control for the deal attitude using a dummy variable; acquisition is friendly, that takes the value of one if the deal was classified as friendly in SDC, and zero if otherwise. To capture the effect of the payment method we use a dummy variable, cash payment, that is coded as one if $95 \%$ or more of the transaction is paid in cash, and zero if otherwise. We also controlled for two target firm characteristics. First, we captured whether another firm divested the acquisition target. Divestiture was coded as a dummy variable taking the value of one if another firm divested the acquisition target, and zero if otherwise. Second, we also included a dummy variable taking the value of one if the target is publicly listed, and zero if otherwise.

To control for firm-level effects, we have included variables that capture firm size, $R \& D$ intensity, and performance at $t-1$. Firm size is measured as the logarithm of total assets and R\&D intensity as R\&D spending in relation to total assets. Performance is measured using the market-based measure Tobin's $Q$. We measured Tobin's $Q$ as follows: ([Closing share price ${ }^{*}$ common shares outstanding] + total assets - total common equity)/total assets (Cai \& Vijh, 2007). ${ }^{4}$ We also include a number of variables that capture the experience and associated isomorphic pressures the MNC may be exposed to. First, we control for host country acquisition experience. Host country acquisition experience is measured as the number of completed full acquisitions (over $95 \%$ equity stake) in the same host country in the three-year period prior to the transaction. Similarly, we have also controlled for overall full acquisition experience measured as the number of completed full acquisitions conducted in a 3-year period prior to the focal transaction. Finally, we control for the average past equity stake taken in all past acquisitions. ${ }^{5}$

Lastly, we control for a number of CEO level effects. We control for CEO age (in years) given that older CEOs may be more risk-averse (Musteen et al., 2009). To account for variance in home country compensation norms across industries we include the average total compensation of all CEOs listed in the Execucomp database measured at the four-digit SIC level as industry average compensation. We further control for factors that may determine the CEO's power over the board. First, we control for CEO tenure (in months) in light of evidence that longer-tenured CEOs have greater influence over the board (Hambrick \& Fukutomi, 1991). Second, board-chair CEOs are also expected to be in a better position to advance and endorse personal preferences (Hambrick \& Fukutomi, 1991); we, therefore, control for CEO duality. CEO duality is measured as a dummy variable that is coded as one if the CEO also serves as chairman, and zero if otherwise. We have also included two control variables related to the CEO's compensation. CEO restricted stock was measured as the aggregated cash value of the CEO's restricted stock holdings at fiscal yearend. CEO cash compensation is measured as the sum of cash payments and bonuses the CEO has received. Both CEO compensation control variables are measured at $t-1$. We also include year dummies, with 1993 being the omitted value.

\section{4 | RESULTS}

The descriptive statistics and correlations are presented in Table 1. It is noteworthy that the equity stake deviation varies from 0 to $90 \%$ indicating that some firms deviate strongly from the industry norm. ${ }^{6}$ In our sample, the average equity stake acquirers take in foreign targets is $93.98 \%$ (SD 18.43\%) (compared to $87 \%$ [SD 26\%] in a study by Cuypers, Ertug, \& Hennart, 2015 and 89\% [SD 24\%] in a study by Chari \& Chang, 2009). The slightly higher average equity stake acquirers take in foreign targets may be explained by our focus on U.S. firms, whereas other studies have focused on an international sample (Cuypers et al., 2015) or also included financial services firms (Chari \& Chang, 2009). Interestingly, we also observe that there is a significant increase in the equity stake taken in foreign targets over the duration of our sample period. The difference between the average equity stake in 1993 and 2016 is 7.61 percentage points. A t test confirmed that this difference is unlikely to be zero $(t[266]=3.333$, $p=.001)$. Thus, the higher average equity stake in our sample may be because our sample includes relatively more recent observations, a finding that is consistent with Chari and Chang (2009) who also find an increasing trend in the share of equity sought. Finally, as noted above, we excluded deals with less than $10 \%$ equity because they are considered portfolio investments rather than Foreign Direct Investment (FDI). Hence, the average and SD in our study are calculated without very low equity stakes.

As can be seen, there are some relatively large correlations between the host country governance and other institutional variables. To further analyze these correlations, we have run postregression collinearity diagnostics. It has been suggested that the threshold for serious multicollinearity is a variance inflation factor (VIF) of 10 (Cohen, Cohen, West, \& Aiken, 2003, p. 423). Our postregression multicollinearity diagnostics demonstrate that the VIF for all first-order variables is below this threshold with a mean VIF of 2.66 and a highest individual VIF of 8.20 (for the host country governance variable). If we drop the host country GDP per capita variable (it has the second-highest individual VIF of 8.06) from the analysis the mean VIF becomes 2.19 , the VIF for the host country governance variable becomes 3.27 , and the results remain very 


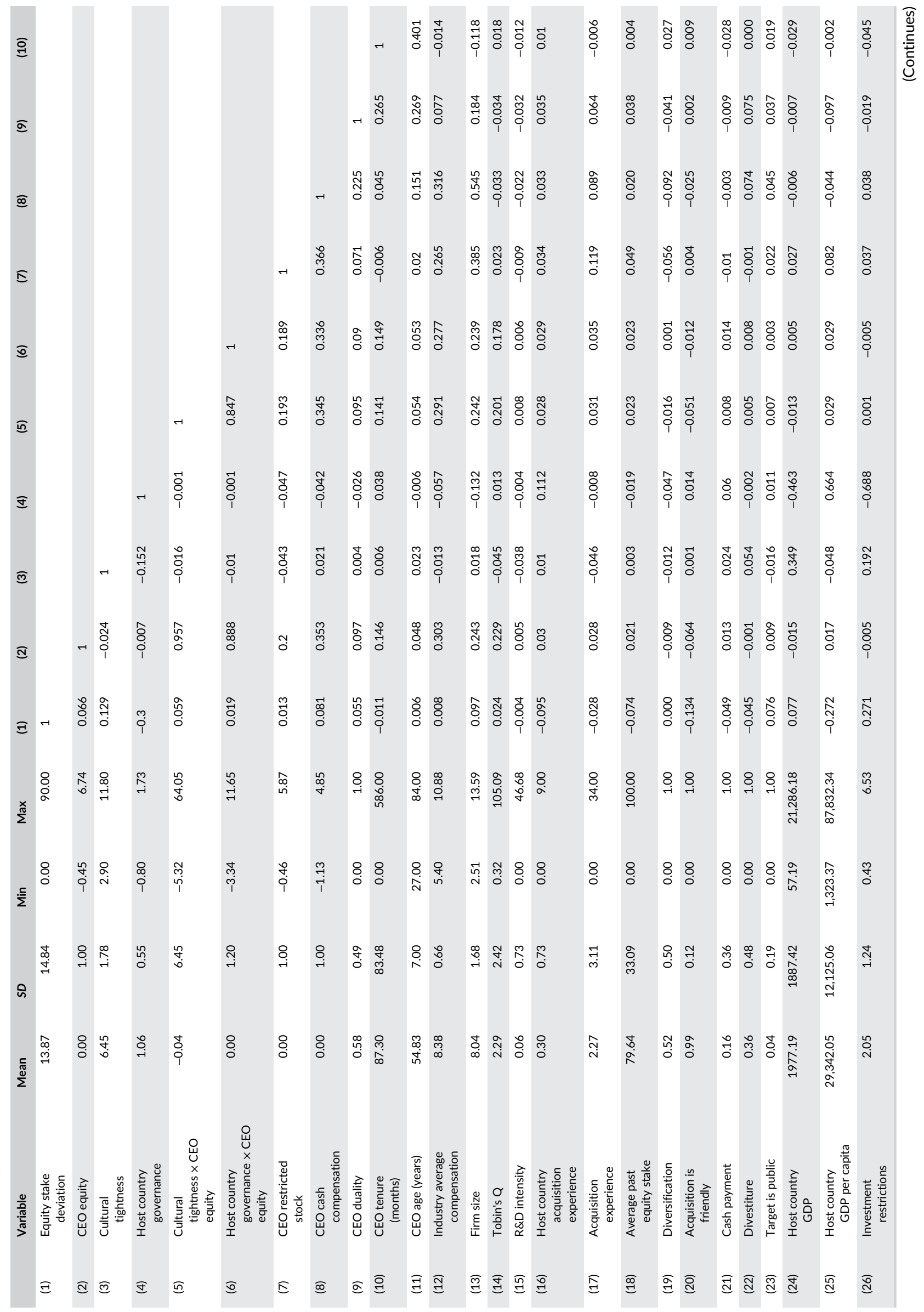




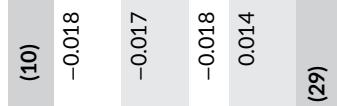

ब

๔

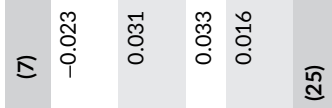

ฮ

ธת

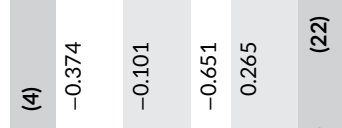

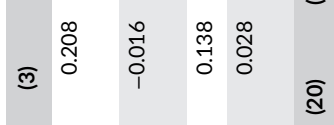

ฮิ

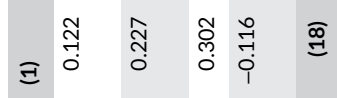

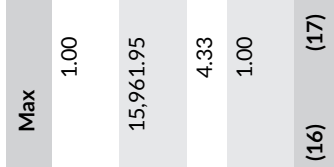

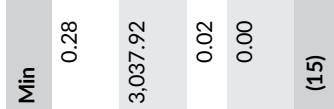

in

또․

离

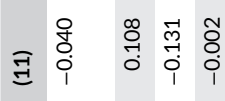

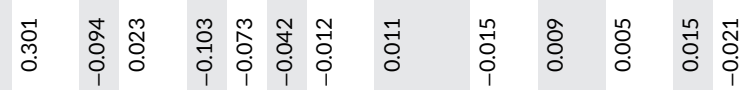

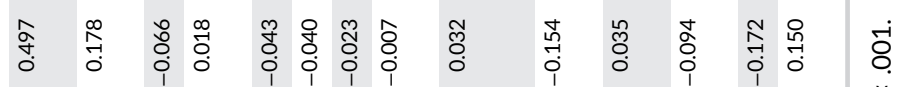
商

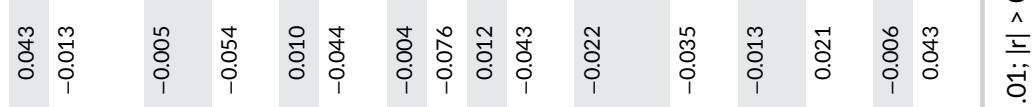

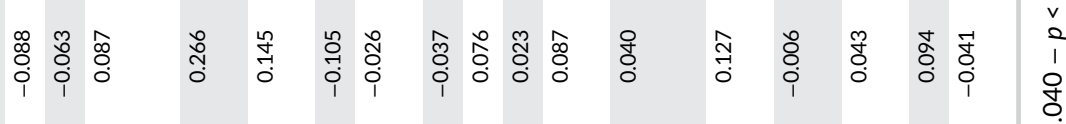

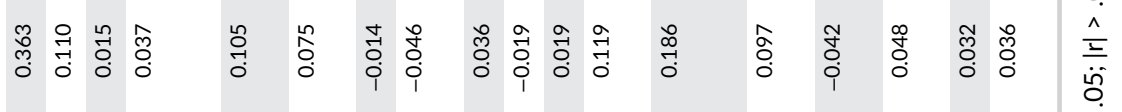

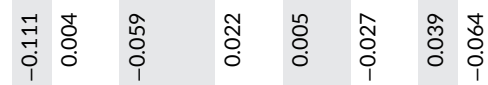

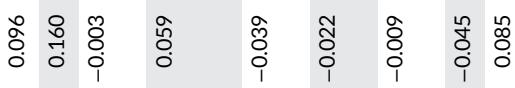

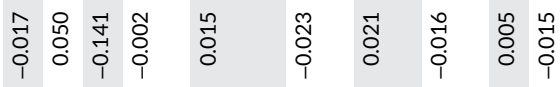
ఫิ 范 
TAB LE 2 Regression results CEO equity on equity stake deviation

\begin{tabular}{|c|c|c|c|c|c|c|}
\hline & Model (1) & Model (2) & Model (3) & Model (4) & Model (5) & Model (6) \\
\hline \multirow[t]{2}{*}{ Constant } & 14.710 & 16.291 & 17.373 & 16.487 & 17.441 & 16.530 \\
\hline & (6.178) & (6.219) & $(6.604)$ & (6.510) & (6.636) & $(6.557)$ \\
\hline \multirow[t]{2}{*}{ Host country GDP } & 0.000 & 0.000 & -0.000 & -0.000 & -0.000 & -0.000 \\
\hline & $(0.000)$ & $(0.000)$ & $(0.000)$ & $(0.000)$ & $(0.000)$ & $(0.000)$ \\
\hline \multirow[t]{3}{*}{ Host country GDP per capita } & -0.000 & -0.000 & -0.000 & -0.000 & -0.000 & -0.000 \\
\hline & $(0.000)$ & $(0.000)$ & $(0.000)$ & $(0.000)$ & $(0.000)$ & $(0.000)$ \\
\hline & {$[0.000]$} & {$[0.000]$} & [0.746] & [0.725] & {$[0.746]$} & {$[0.724]$} \\
\hline \multirow[t]{2}{*}{ Investment restrictions } & 0.337 & 0.333 & -0.450 & -0.486 & -0.457 & -0.491 \\
\hline & (0.388) & (0.386) & $(0.380)$ & $(0.378)$ & $(0.379)$ & $(0.378)$ \\
\hline Host country political risk & [0.959] & [0.970] & [0.273] & [0.254] & {$[0.264]$} & [0.253] \\
\hline \multirow[t]{3}{*}{ Geographic distance } & 0.001 & 0.001 & 0.001 & 0.001 & 0.001 & 0.001 \\
\hline & $(0.000)$ & $(0.000)$ & $(0.000)$ & $(0.000)$ & $(0.000)$ & $(0.000)$ \\
\hline & {$[0.000]$} & {$[0.000]$} & [0.000] & [0.000] & {$[0.000]$} & [0.000] \\
\hline \multirow[t]{3}{*}{ Cultural distance } & 2.882 & 2.877 & 1.639 & 1.637 & 1.647 & 1.642 \\
\hline & $(0.338)$ & $(0.337)$ & $(0.357)$ & $(0.359)$ & $(0.357)$ & $(0.361)$ \\
\hline & {$[0.000]$} & {$[0.000]$} & [0.000] & [0.000] & {$[0.000]$} & [0.000] \\
\hline Common official language & -1.374 & -1.401 & -2.600 & -2.653 & -2.586 & -2.645 \\
\hline \multirow{2}{*}{ Acquisition is friendly } & (3.752) & (3.652) & (3.600) & (3.538) & (3.605) & (3.549) \\
\hline & {$[0.000]$} & {$[0.000]$} & [0.000] & [0.000] & {$[0.000]$} & [0.000] \\
\hline \multirow[t]{3}{*}{ Cash payment } & -0.715 & -0.744 & -0.723 & -0.709 & -0.720 & -0.708 \\
\hline & (0.519) & $(0.517)$ & $(0.515)$ & $(0.514)$ & $(0.514)$ & $(0.514)$ \\
\hline & [0.169] & [0.151] & [0.160] & [0.168] & {$[0.162]$} & [0.169] \\
\hline \multirow[t]{3}{*}{ Divestiture } & -2.286 & -2.265 & -2.260 & -2.240 & -2.262 & -2.242 \\
\hline & $(0.450)$ & (0.448) & (0.444) & $(0.442)$ & $(0.444)$ & $(0.442)$ \\
\hline & {$[0.000]$} & [0.000] & [0.000] & [0.000] & {$[0.000]$} & [0.000] \\
\hline \multirow[t]{3}{*}{ Target is public } & 2.471 & 2.571 & 2.674 & 2.696 & 2.670 & 2.694 \\
\hline & (1.720) & (1.715) & (1.744) & (1.745) & $(1.745)$ & (1.747) \\
\hline & [0.151] & [0.134] & [0.125] & [0.123] & {$[0.126]$} & [0.123] \\
\hline \multirow[t]{3}{*}{ Firm size } & 0.843 & 0.797 & 0.731 & 0.751 & 0.730 & 0.751 \\
\hline & (0.189) & (0.189) & (0.191) & (0.189) & $(0.192)$ & (0.190) \\
\hline & {$[0.000]$} & {$[0.000]$} & [0.000] & [0.000] & {$[0.000]$} & [0.000] \\
\hline \multirow[t]{3}{*}{ Tobin's Q } & 0.055 & 0.002 & 0.012 & -0.003 & 0.013 & -0.002 \\
\hline & $(0.096)$ & $(0.074)$ & (0.078) & $(0.071)$ & $(0.078)$ & $(0.071)$ \\
\hline & [0.564] & [0.981] & [0.878] & [0.967] & {$[0.863]$} & [0.978] \\
\hline
\end{tabular}


TABLE 2 (Continued)

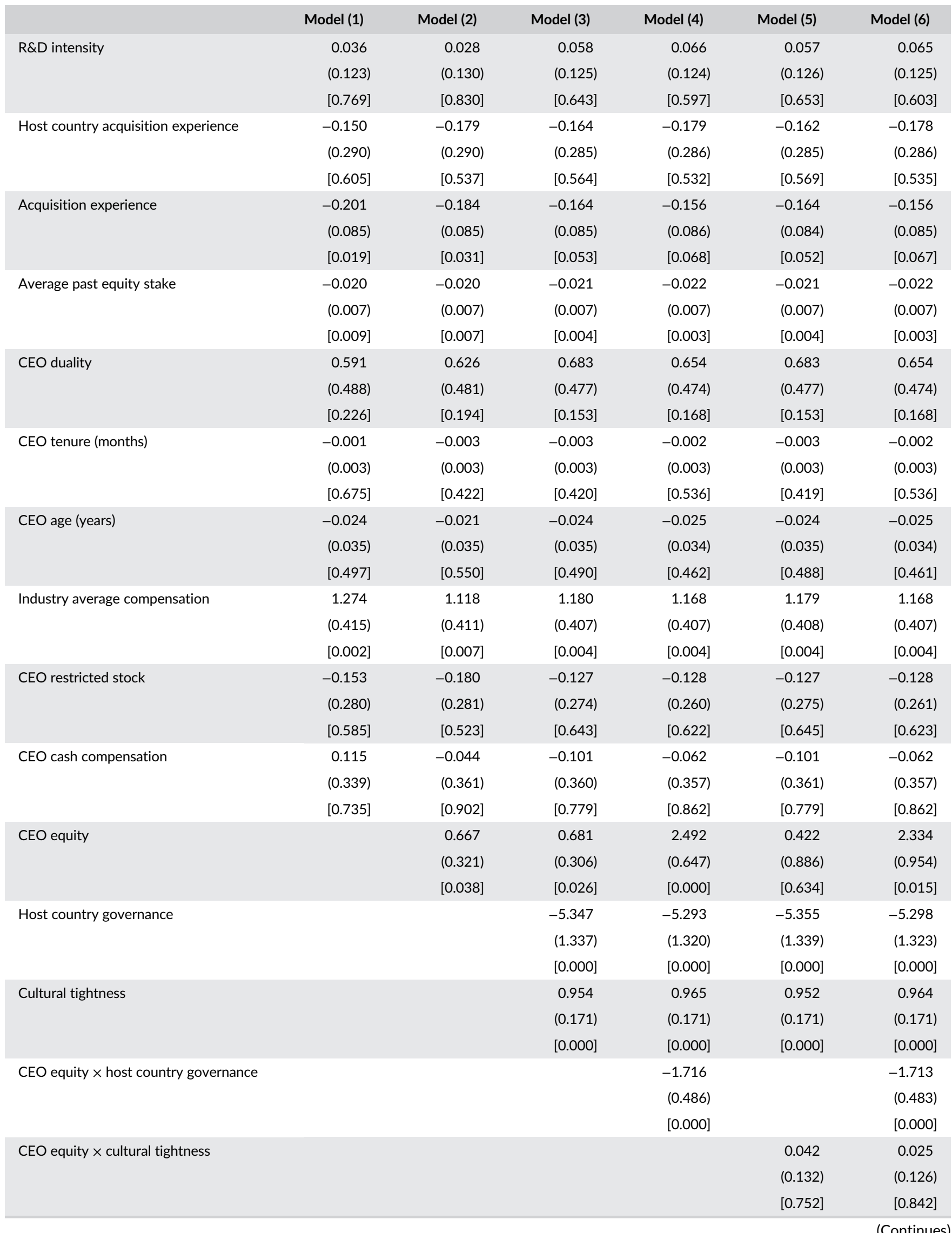


TABLE 2 (Continued)

\begin{tabular}{|c|c|c|c|c|c|c|}
\hline & Model (1) & Model (2) & Model (3) & Model (4) & Model (5) & Model (6) \\
\hline Years & Yes & Yes & Yes & Yes & Yes & Yes \\
\hline Adj. $R^{2}$ & 0.224 & 0.225 & 0.241 & 0.245 & 0.241 & 0.244 \\
\hline$F p$-value & .000 & .000 & .000 & .000 & .000 & .000 \\
\hline$d f$ & 47 & 48 & 50 & 51 & 51 & 52 \\
\hline
\end{tabular}

Notes: SE adjusted for clustering by acquirer in parentheses. $p$-Values in brackets. Results are for two-tailed tests. All models included dummy variables for each year with 1993 as the reference year. Results for year dummies are not included.

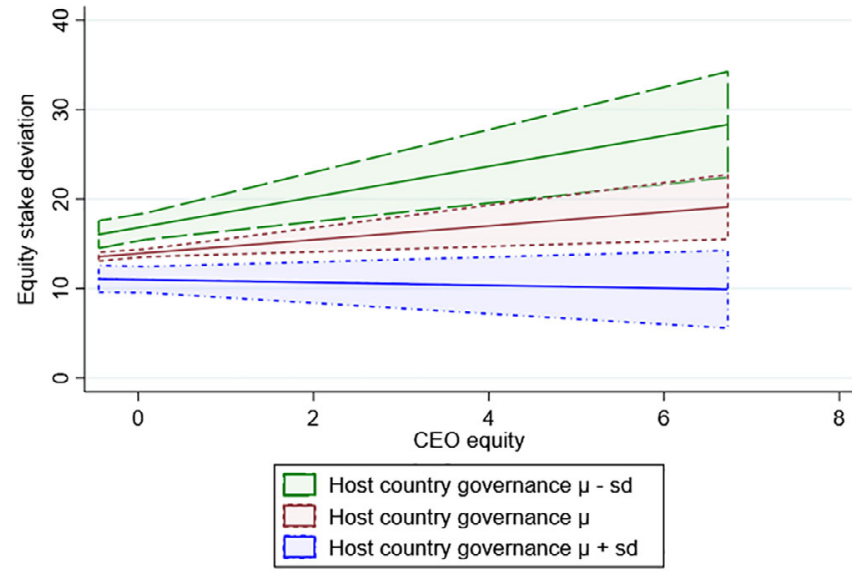

Note: $95 \%$ confidence intervals are displayed as dashed lines

FIGURE 1 CEO equity and predicted equity stake deviation for host country governance

similar. Hence, we take a more conservative approach and retain the variable in the analysis (full results available upon request).

The results of the hypotheses tests are presented in Table 2. Model 1 of Table 2 is the baseline model including only control variables. Model 2 introduces the CEO equity variable and shows a significant positive ( $b=.667, p=.038$ ) effect on equity stake deviation. This suggests that the risk-bearing inherent to CEO equity increases the deviation from the industry norm when deciding on the equity stake taken in a foreign target. Regarding effect size, when CEO equity compensation increases by $1 S D$ from the mean, the deviation from the industry norm increases from 13.86 percentage points to 14.53 percentage points. Hence, we conclude that Hypothesis 1 is supported.

Model 3 of Table 2 introduces the two moderating variables. Model 4 introduces the interaction terms used to test Hypothesis 2 . The "host country governance $\times$ CEO equity" interaction is negative and significant $(b=-1.716, p=.000)$. In addition, we plot the effect in Figure 1. It can be seen that as CEO equity compensation increases, the equity stake deviation decreases when host country governance increases. The figure also illustrates the effect size. At the mean level of CEO equity compensation, when host country governance increases by $1 S D$ from the mean, the deviation from the industry norm decreases from 13.86 percentage points to 10.94 percentage points. Thus, we conclude that Hypothesis 2 is supported.

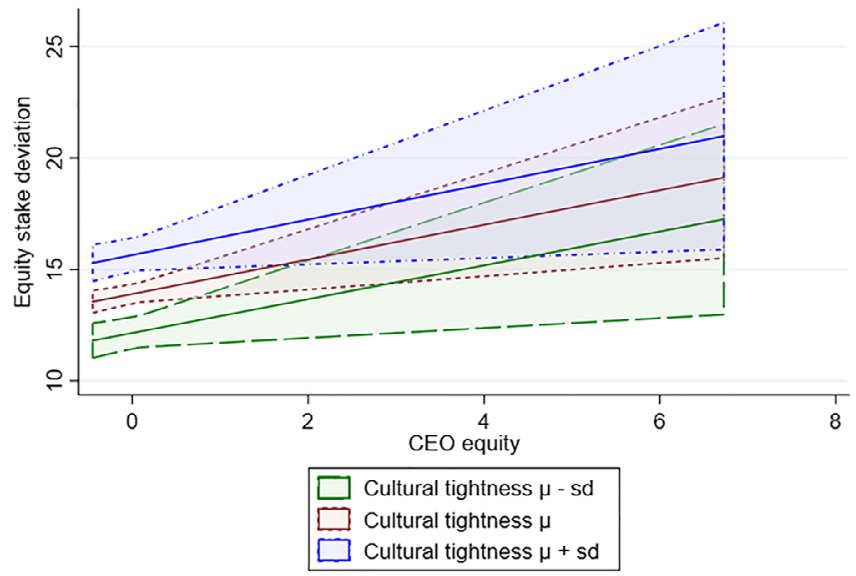

Note: $95 \%$ confidence intervals are displayed as dashed lines

FIGURE 2 CEO equity and predicted equity stake deviation for cultural tightness

Model 5 introduces the interaction term used to test Hypothesis 3 . The "cultural tightness $\times$ CEO equity" interaction is positive but not significant ( $b=.024, p=.752$ ). Figure 2 illustrates the moderating effect of cultural tightness. It can be seen that as cultural tightness increases this merely shifts the intercept but does not alter the relationship between CEO equity compensation and equity stake deviation. Hypothesis 3 is thus not supported. Model 6 presents the fully specified model and further corroborates our results from Models 1-5.

With respect to control variables, we interpret the results in the fully specified Model 6 in Table 2. Interestingly, we find that in more geographically distant $(p=.000)$ and more culturally distant $(p=.000)$ host countries firms deviate more from industry norms whereas in host countries that share an official language $(p=.000)$ with the home country firms deviate less from industry equity stake norms. This indicates that the social institutional environment may play an important and diverse role in enforcing industry norms. Of the transaction level control variables, friendly acquisitions $(p=.000)$ and acquisitions of a divested unit $(p=.000$ ) deviate less from industry norms. In regard to firm-level control variables, larger firms $(p=.000)$ deviate more from industry norms while the average past equity stake firms have taken is negatively $(p=.001)$ associated with deviating from the industry norm. In addition, higher industry average compensation in the home 
country is positively $(p=.004)$ associated with deviate more from industry norms in the host country.

\subsection{Endogeneity and robustness tests}

We conduct a number of supplemental analyses to check the robustness of our results (all results are available upon request). First, it is likely that firms self-select into cross-border acquisition. Thus it is likely that firms are not randomly assigned to our sample. If this is the case, and we do not account for this in our estimation, this could lead to biased estimates (Shaver, 1998). To test if selection influences our results we use all firms listed in the Compustat database (excluding financial services firms) to compute the inverse Mills ratio (Heckman, 1979) and then include this ratio to control for selection in our models. To compute the inverse Mills ratio, we estimate a random effects probit model. In this model, the dependent variable takes the value of 1 if a firm announced a cross-border acquisition in a given year and 0 if otherwise. The independent variables used in this model are the CEO level control and compensation variables and the firmlevel control variables described above. We also include year dummy variables.

To identify selection in this model, we need to include an instrument that is correlated with the probability of announcing a crossborder acquisition, but that is not correlated with the equity deviation from the industry norm in the host country. The instrumental variable we use is home country industry concentration measured as the Herfindahl-Hirschman index (at the two-digit SIC level). We believe this is a valid instrument because firms engage in acquisitions in general (Haleblian, Devers, McNamara, Carpenter, \& Davison, 2009) and internationalization in particular (Shaver, 1998) in response to competitive pressure in the home market. Also, we have no reason to believe that domestic competitive pressure would influence the equity stake deviations from the industry norm in a given host country. When estimating the selection model, all CEO compensation variables, CEO gender, firms size, and firm performance are significant predictors. The effect of industry concentration is negative and significant $(p=.001)$ in the selection model. In addition, when we include home country industry concentration in the models presented above, the effect remains insignificant $(p>.05)$ in all models. Therefore, we are satisfied that the instrument satisfies exclusion restrictions. When we re-estimate our models including the inverse Mills ratio, the variable remains insignificant in all models, but our results remain consistent with those reported in our main analyses. Hence, we are confident that self-selection does not influence our results.

One other possible concern with the findings presented here is that unobservable country, firm, or CEO effects may be introducing endogeneity leading to biased estimates. To probe this possibility, we follow Papke and Wooldridge (2008) suggestion to include average values, an approach known as the Chamberlain-Mundlak device. This approach is similar to a fixed effects estimator, but rather than demeaning the data for estimation; the mean values are modeled explicitly. Specifically, we compute the firm-specific average for performance, firm size, $R \& D$ intensity, host country acquisitions experience, acquisition experience, and average past equity stake. We also compute CEO specific averages for CEO duality, CEO tenure, CEO age, and industry average compensation. In addition, we compute host country specific averages for GDP, GDP per capita, investment restrictions, and political risk (the other host country level variables do not vary over time). We re-estimate our models including these averages and receive very similar results. Postestimation analyses do, however, reveal that these models potentially suffer from multicollinearity, and hence we prefer the models reported in our main analyses.

While we control for a range of host country variables, there may be unobserved host country characteristics, and there may be differences in effects across host countries and regions. ${ }^{7}$ To test for this possibility, we re-estimate all our models including host country dummy variables. The results we obtain with this approach are similar to the results reported above, and only two host countries (Belgium and France) exhibit a positive and significant coefficient indicating that these countries differ from the reference category (the United Kingdom) in terms of equity stake deviations. The hypothesized results remain consistent with those reported in our main analyses. Please note, however, that post hoc VIF analysis shows that the country dummy variables are highly correlated with some country level control variables (geographic distance, cultural distance, and common official language) and the moderating variables (cultural tightness and host country governance). Therefore, to further test for country differences, we re-estimate our models excluding our country level control variables and using country dummy variables instead. The hypothesized results are also consistent with those reported in our main analyses. Again, these results have to be interpreted with caution given that although this approach reduces collinearity (mean VIF is 18.16), many of the country control dummies and the moderating variables still exhibit VIFs that are well above the critical value of 10 .

In a similar vein, there may also be some unobserved supraregional level differences in decisions to deviate from the norm (Rugman \& Verbeke, 2004). To test for such regional level differences, we have created regional dummy variables base on broad supra-national regions (Europe, Asia, Americas [excluding the United States as this is the home country], and rest of the world). We have then included these variables as dummy variables and re-estimated our models. In this analysis, the Asia dummy variable is positive and significant in all models indicating that in the Asian region, there are higher equity stake deviations when compared with Europe while the other regional dummy variables remain insignificant at conventional levels in all models. Importantly, the results for our main variables remain consistent across all models.

It is also important to consider that our study period covers the time of the global financial crisis. To account for the possibility that the global financial crisis may have affected our results, we also estimate models that include a dummy variable that takes the value of one for the years 2007,2008 , and 2009 , and zero if otherwise. However, we are unable to include this variable in our analysis because it is highly correlated to our year dummies. We have therefore re-run 
our analyses without the year dummies and instead re-estimated our models using the financial crisis dummy variable. When using this approach, our main results remain consistent with the results presented above.

Our arguments suggest that CEOs trade-off legitimacy risk and business risk in equity stake decisions. However, everything else being equal, acquisitions in which a firm acquires less than $50 \%$ of equity may also be riskier than acquisitions with higher equity stakes because they do not give full control and may make it more difficult to control the target firm. To account for the possibility that this effect could influence our results we drop all deals in which a firm acquired less than $50 \%$ equity. When we re-estimate our models, the results remain consistent with the results presented here.

Finally, as described above, we define the reference group that determines the industry norm at the host country-industry level. To probe how alternative definitions of the reference group affect our results we test alternative reference periods. First, we use a 2-year and a 4-year window when calculating the industry norm. Reestimating our models with these alternative measures yields similar results. Second, it may be that the most relevant reference groups are only firms from the same home country (the United States) rather than all foreign firm acquisitions. Hence, we re-estimate our models using only acquisitions by U.S. firms when defining the industry norm. In these models, the effect for the CEO equity $\times$ host country governance interaction is stronger than the effect reported in the main analysis (Model 6: $b=-2.027 ; p=.002$ ) while the direct effect of the CEO equity variable is no longer significant (Model 2: $b=0.446$; $p=.250$ ). It could also be assumed that all acquisitions in the host country (rather than just foreign firm acquisitions) form the relevant reference group. Accordingly, we re-estimate our models using all acquisitions in the focal host country when defining the industry norm. Interestingly, in these models the direct effect of CEO equity is no longer significant (Model 2: $b=.463 ; p=.134$ ) and the moderating effect of host country governance becomes weaker (Model 6: $b=-0.714$; $p=.051)$. However, the interaction of CEO equity $\times$ cultural tightness now becomes negative and marginally significant (Model 6: $b=-.190$; $p=.064)$. In sum, while these alternative specifications of the reference group generally support the pattern of the results we observe in the main analyses, they also highlight that it is important to consider alternative reference groups.

\section{5 | DISCUSSION AND CONCLUSION}

The objective of this study has been to advance understanding of how CEO incentives influence their responses to institutional pressure in foreign market entry decisions. Specifically, we have focused on the role of managerial agency in response to CEO equity risk bearing when explaining CEOs' decisions to deviate from institutional norms. Our results show that MNCs whose CEOs have higher risk bearing (due to incentives) are more likely to deviate from the industry norm when deciding upon the equity ownership stake taken in a foreign target. We further find that this effect is weaker as host country governance quality increases. We find no statistically significant moderating effect of cultural tightness. Taken together, the pattern of our results supports our prediction that CEOs with larger equity risk bearing are willing to accept higher legitimacy risk in exchange for lower levels of business risk (as reflected in the deviation from the industry norm). We believe that our findings have important implications for HRM practice and theory.

Most notably, we advance knowledge within the HRM literature regarding how incentives influence CEO behaviors. Specifically, we demonstrate that incentives are not sufficient to predict CEO decision making in the context of foreign market entry decisions. Neither are institutional factors sufficient to predict these CEO decisions. Indeed, our findings suggest that both CEO incentives and host country institutional pressures should be considered when predicting CEO preferences regarding equity stake decisions in cross-border acquisitions. While prior HRM research linking CEO incentives to MNC strategy has conceptualized the entry mode decision as a discrete choice between a given set of entry modes (Slangen \& Hennart, 2007), we offer an alternative perspective that focuses on the degree to which CEO incentives explain MNCs likelihood to deviate from industry norms when expanding abroad. This shifts the focus from studying discrete choices using either incentives or institutional perspectives. Instead, we explore how CEO incentives explain heterogeneous responses to host country institutional pressures using an integrated incentive and institutional approach.

Our findings, however, are not only important to develop theory explaining the persistence of heterogeneous MNC responses to host country institutional pressures (e.g., Bae et al., 1998; Cantwell et al., 2010; Faulconbridge \& Muzio, 2016; Holm et al., 2017; Regner \& Edman, 2014), but also points toward a more complex relationship between CEO incentives and MNC responses to institutional norms. In particular, previous HRM research exploring CEO incentives has tended to overlook the social or institutional embeddedness of executives and their firms (Wiseman, Cuevas-Rodriguez, \& Gomez-Mejia, 2012; Zolotoy et al., 2018) and the few studies combining institutional perspectives with agency theory have focused on explaining how CEO incentives reinforce institutional norms (e.g., Berrone \& GomezMejia, 2009; Gomez-Mejia, Berrone, \& Franco-Santos, 2010). Contrasting the notion that CEO incentives may reinforce institutional norms, our study shows that in the context of foreign market entry choices, CEO incentives can also explain deviations from institutional norms. While this finding is consistent with the main argument in prior work that CEOs make decisions with regards to either their incentives (e.g., Musteen et al., 2009) or institutional forces (e.g., Ang et al., 2015), our study combines these literatures to add the novel insight that, in situations in which business and legitimacy risk are asymmetric, CEO incentives can also shift the focus from legitimacy to business risk reduction. This shift in focus from legitimacy to business risk reduction due increases in CEO equity risk bearing, therefore, leads to a greater likelihood of deviations from institutional norms. This adds a new dimension to institutional conformance research by Oliver (1991) through demonstrating that CEO incentives can also explain heterogeneous responses to institutional pressures. 
More broadly, our study also advances agency theory and HRM literature's conceptualization of the behavioral effects of incentives by addressing the criticism that both are under-socialized (Miller, Hom, \& Gomez-Mejia, 2001; Wowak, Gomez-Mejia, \& Steinbach, 2017). Modeling of the principal-agent relationship typically fails to consider social and institutional constraints that are likely to affect CEO decision making (Trevino, Gomez-Mejia, \& Balkin, 2018; Wiseman et al., 2012). For instance, the agency literature has only sparsely explored the extent to which the institutional environment may influence managerial agents to act opportunistically (Aguilera \& Jackson, 2003). Our study's findings, therefore, complement prior research by offering theory that explains how CEO opportunism intersects with institutional norms to shape important decisions. Specifically, we provide the insight that it is important to also consider social expectations (or legitimacy concerns) within the institutional field when predicting agent risk behavior. As such, our study has highlighted important boundaries to previous corporate governance literature suggesting that agent risk bearing associated with equity based incentives influence agent risk taking (Benischke et al., 2019; Devers et al., 2008; Larraza-Kintana et al., 2007; Martin et al., 2013). These studies have argued that the CEO will avoid high risk strategies at higher levels of CEO firm-specific wealth-at-risk (or risk bearing). CEO/agent's concentration of firm-specific wealth has long been argued by agency scholars to create agency costs for shareholders who are less risk averse (based on the assumption that shareholders have diversified portfolios; Holmstrom, 1979; Shavell, 1979). We refine these arguments by theorizing that this risk aversion created by risk bearing can also affect internationalization decisions when CEOs attempt to mitigate business risk potentially created by those decisions. According to agency theory, it is likely that the CEO is more willing to mitigate this risk, hence deviating from industry norms, than their shareholders.

In terms of the foreign market entry literature, this literature has explored numerous firm and contract level factors influencing these decisions. From a transaction cost perspective, higher levels of uncertainty or asset specificity could lead to acquisitions with higher equity stakes or organic expansion to internalize transactions between the host and home country entities (Hernandez \& Guillén, 2018). Real options suggest that uncertainty leads to lower equity stakes-at least initially-so that more information can be attained before making a further investment (Brouthers \& Hennart, 2007). Our study complements those perspectives by demonstrating that, after controlling for uncertainty and prior investment levels, CEO incentives influence the institutional effect (conform by taking equity stakes similar to others). In doing so, we hope to have advanced foreign market entry literature.

We do not find empirical support for our predicated moderation effect of cultural tightness. While this result is surprising, it could be due to more complex interactions between culture and more formal aspects of the host country's institutional environment. That is, previous studies indicate that cultural institutions are particularly relevant in the absence of strong formal institutions (Ang et al., 2015). Therefore, CEOs may be less sensitive to constraints associated with cultural institutions on their ability to deviate from the norm as their equity risk bearing increases. Said differently, cultural tightness may not be sufficient to offset the perceived benefits of deviating from the norm in order to protect their wealth-at-risk of loss.

\section{1 | Practical implications for human resource professionals and their boards}

For HRM professionals, our study provides the insight that CEO incentives interact with institutional context to predict decision making with regard to major strategic initiatives, such as foreign expansion. Importantly, CEO incentives are influential in and of themselves, however perhaps not as influential as the previous literature has implied. Hence, we elucidate the shortcomings of incentives as a lever for influencing CEO behaviors. The board and the HRM executives who support them must analyze the institutional context to anticipate CEO behaviors. If there is concern that the CEO will respond to institutional pressure through behaviors that the board believes are not consistent with the long-term interests of important firm stakeholders, our study suggests that incentives can be designed in a way that could mitigate the CEO's tendency to conform with peer behaviors. Moreover, if the incentives are designed without heed to the insight that CEO behaviors are influenced by both incentives and institutional norms, there is an increased risk that HRM teams could inadvertently encourage behaviors that may improve firm legitimacy in the short-term, but increase the probability of firm failure in the longer term.

For boards of directors attempting to influence their CEO, we provide a theoretical framework that helps them understand how their CEO has formed opinions on internationalization decisions. For shareholders who are looking to invest in a business whose future depends on cross-border expansion, our framework allows the shareholders to anticipate whether they will be investing in a business whose CEO is likely to help deliver on their vision. Such a framework may allow a shareholder to avoid agency costs due to likely misalignment between CEO incentives, institutional norms, and the choices the shareholder would like the CEO to make in the future. For debt or equity investors skeptical about cross-border acquisitions, our framework may allow them to avoid investing in businesses whose CEO is inclined to pursue such acquisitions, based on an assessment of the CEO's incentives and the institutional norms.

\subsection{Limitations and future research}

While our results offer important insights, this study is not free of limitations. First, we have focused on one form of institutional pressures; that is, mimetic institutional pressures. There are, however, other forms of institutional pressures, namely coercive and normative pressures, which also play an important role in isomorphic processes (although these are less relevant in the decision context of this study which focuses on a within country, within industry governance choices). While there is no reason to believe that our theoretical 
framework cannot be applied to these different forms of pressures, we encourage future research to validate our findings by replicating our model with other forms of institutional pressures. Second, we believe that there is an opportunity to explore how different CEOboard relationships might further alter the hypothesized relationships. For example, it might be possible that CEOs with greater power over their boards have a greater amount of social resources which should strengthen the proposed moderating effects. Similarly, firm level factors may interact with CEO incentives to influence foreign market entry decisions. Lastly, our results are based on data from U.S. firms. The focus on U.S. firms allows us to better attribute cross-border acquisition decisions to the CEO given that those CEOs have relatively greater discretion than their counterparts in other countries (Crossland \& Hambrick, 2011). Future research could pursue the question if the effects reported in our study vary across home countries due to differences in institutional environments.

\section{ACKNOWLEDGEMENTS}

This paper has greatly benefited from insights from Jonathan Doh, Remzi Gozubuyuk, Siah H. Ang, and Jaeyong Song and Bo Nielsen as part of the JIBS Paper Development Workshop and seminar participants at the Academy of International Business Annual Meeting, Strategic Management Society Annual International Conference, University of Auckland, BI Norwegian Business School, and Rotterdam School of Management. A previous version (single-authored by the first author), has been awarded the "Haynes Prize for the Most Promising Scholar" at the 2013 Academy of International Business Annual Conference.

\section{ORCID}

Geoffrey P. Martin (D) https://orcid.org/0000-0001-8898-5323

\section{ENDNOTES}

${ }^{1}$ Consistent with prior research (Amit \& Wernerfelt, 1990; Gomez-Mejia, Haynes, Nunez-Nickel, Jacobson, \& Moyano-Fuentes, 2007; LarrazaKintana, Wiseman, Gomez-Mejia, \& Welbourne, 2007; Miller, Wiseman, \& Gomez-Mejia, 2002), we define business risks as the likelihood of performance failures, or lower than expected returns when the firm makes particular strategic choices under bounded rationality. Legitimacy risk, on the other hand, refers to the potential harm to the organization resulting from lack of compliance with institutional norms or expectations (Suchman, 1995). Hence, if business risk refers to the downside unpredictability of business outcomes, which has been measured in terms of the probability and magnitude or potential downside outcomes (Bromiley, Miller, \& Rau, 2001; Sanders \& Hambrick, 2007; Tosi \& Gomez-Mejia, 1989), drawing on this logic, legitimacy risk refers to the probability of adverse outcomes for firm legitimacy.

${ }^{2}$ Although prior studies assume that taking a greater equity stake in a target is generally associated with greater risk (e.g., Musteen et al., 2009), we acknowledge that this is not always the case. Our theory suggests that the business risk when acquiring an equity stake in a target in crossborder acquisitions is not primarily a function of the size of the equity stake but rather of the mismatch between industry norm and firmspecific resources and capabilities that would determine the optimal (firm-specific) equity stake.

${ }^{3}$ Some studies also consider the possibility that an increase in equity compensation motivates CEOs to take greater business risks (e.g., Sanders \& Hambrick, 2007); however, this is only the case in situations in which their equity compensation is largely insulated from downside risk (Martin et al., 2013; Wiseman \& Gomez-Mejia, 1998) which is not the case in the context of this study.

${ }^{4}$ We also use an accounting-based measure of performance in sensitivity testing. In particular, we use return on assets measured as net income divided by total assets. Using this alternative measure yields similar results.

${ }^{5}$ We also included a control variable that captures the focal firm's ownership concentration. Although the ownership concentration variable is significant at the 0.1 level, the results are qualitatively similar to those reported in our main models. We did not include this variable in our main models given that we were able to obtain the data necessary to calculate this variable for only $37 \%$ of observations included in our full sample.

${ }^{6}$ The maximum deviation is $90 \%$ given that we exclude portfolio investments from our analyses (acquisitions whereby less than $10 \%$ equity is acquired in the foreign target).

${ }^{7}$ We thank an anonymous reviewer for suggesting these tests.

\section{REFERENCES}

Aguilera, R. V., \& Jackson, G. (2003). The cross-national diversity of corporate governance: Dimensions and determinants. Academy of Management Review, 28(3), 447-465.

Aguinis, H., Martin, G. P., Gomez-Mejia, L. R., Boyle, E. H., \& Joo, H. (2018). The two sides of CEO pay injustice: A power law conceptualization of CEO over and underpayment. Management Research, 16(1), 3-30.

Amit, R., \& Wernerfelt, B. (1990). Why do firms reduce business risk? Academy of Management Journal, 33, 520-533.

Ang, S. H., Benischke, M. H., \& Doh, J. P. (2015). The interactions of institutions on foreign market entry mode. Strategic Management Journal, 36(10), 1536-1553.

Bae, J., Chen, S. J., \& Lawler, J. J. (1998). Variations in human resource management in Asian countries: MNC home-country and host country effects. International Journal of Human Resource Management, 9(4), 653-670.

Bagdadli, S., Hayton, J. C., \& Perfido, O. (2014). Reconsidering the role of HR in M\&As: What can be learned from practice. Human Resource Management, 53(6), 1005-1025.

Balkin, D. B., \& Gomez-Mejia, L. R. (1987). Toward a contingency theory of compensation strategy. Strategic Management Journal, 8, 169-182.

Balkin, D. B., \& Gomez-Mejia, L. R. (1990). The relationship between organizational strategy, pay strategy, and compensation effectiveness. Strategic Management Journal, 11, 153-169.

Barreto, I., \& Baden-Fuller, C. (2006). To conform or to perform? Mimetic behavior, legitimacy-based groups and performance consequences. Journal of Management Studies, 43, 1559-1581.

Baum, J. A. C., Li, S. X., \& Usher, J. M. (2000). Making the next move: How experiential and vicarious learning shape the locations of chains' acquisitions. Administrative Science Quarterly, 45, 766-801.

Benischke, M. H., Martin, G. P., \& Glaser, L. (2019). CEO equity risk bearing and strategic risk taking: The moderating effect of CEO personality. Strategic Management Journal, 40(1), 153-177.

Benson, G. S., Perez-Nordtvedt, L., \& Datta, D. K. (2009). Managerial characteristics and willingness to send employees on expatriate assignments. Human Resource Management, 48(6), 849-869.

Berrone, P., \& Gomez-Mejia, L. R. (2009). Environmental performance and executive compensation: An integrated agency-institutional perspective. Academy of Management Journal, 52(1), 103-126.

Berry, J. (1967). Independence and conformity in subsistence-level societies. Journal of Personality and Social Psychology, 7(4, Pt 1), 415-418.

Boldt, E. D. (1978). Structural tightness and cross-cultural research. Journal of Cross-Cultural Psychology, 9(2), 151-165.

Bragaw, N. A., \& Misangyi, V. F. (2017). The value of CEO mobility: Contextual factors that shape the impact of prior CEO experience on market performance and CEO compensation. Human Resource Management, 56(2), 243-265. 
Brandes, P., Dharwadkar, R., \& Das, D. (2005). Understanding the rise and fall of stock options compensation: Taking principal-agent conflicts to the institutional (battle)field. Human Resource Management Review, 15 (2), 97-118.

Bromiley, P., Miller, K. D., \& Rau, D. (2001). Risk in strategic management research. In M. A. Hitt, R. E. Freeman, \& J. A. Harrison (Eds.), The Blackwell handbook of strategic management. Maiden, MA: Blackwell.

Brouthers, K. D., \& Hennart, J.-F. (2007). Boundaries of the firm: Insights from international entry mode research. Journal of Management, 33(3), 395-425.

Cai, J., \& Vijh, A. M. (2007). Incentive effects of stock and option holdings of target and acquirer CEOs. Journal of Finance, 62(4), 1891-1933.

Cantwell, J., Dunning, J. H., \& Lundan, S. M. (2010). An evolutionary approach to understanding international business activity: The coevolution of MNEs and the institutional environment. Journal of International Business Studies, 41, 567-586.

Carpenter, S. (2000). Effects of cultural tightness and collectivism on self-concept and causal attributions. Cross-Cultural Research, 34(1), 38-56.

Chan, C. M., \& Makino, S. (2007). Legitimacy and multi-level institutional environments: Implications for foreign subsidiary ownership structure. Journal of International Business Studies, 38, 621-638.

Chari, M. D. R., \& Chang, K. (2009). Determinants of the share of equity sought in cross-border acquisitions. Journal of International Business Studies, 40, 1277-1297.

Chua, R. Y. J., Roth, Y., \& Lemoine, J. F. (2014). The impact of culture on creativity: How cultural tightness and cultural distance affect global innovation crowdsourcing work. Administrative Science Quarterly, 60 (2), 189-227.

Chung, C. N., \& Luo, X. R. (2013). Leadership succession and firm performance in an emerging economy: Successor origin, relational embeddedness, and legitimacy. Strategic Management Journal, 34, 338-357.

Cohen, J., Cohen, P., West, S. G., \& Aiken, L. S. (2003). Applied multiple regression/correlation analysis for the behavioral sciences. New York, NY: Routledge.

Cooke, F. L., \& Huang, K. (2011). Postacquisition evolution of the appraisal and reward systems: A study of Chinese IT firms acquired by US firms. Human Resource Management, 50(6), 839-858.

Crossland, C., \& Hambrick, D. C. (2011). Differences in managerial discretion across countries: How nation-level institutions affect the degree to which CEOs matter. Strategic Management Journal, 32(8), 797-819.

Cuypers, I. R. P., Ertug, G., \& Hennart, J. F. (2015). The effects of linguistic distance and lingua franca proficiency on the stake taken by acquirers in cross-border acquisitions. Journal of International Business Studies, 46, 429-442.

Datta, D. K., Musteen, M., \& Herrmann, P. (2009). Board characteristics, managerial incentives, and the choice between foreign acquisitions and international joint ventures. Journal of Management, 35(4), 928-953.

Denya, B., Gomez-Mejia, L. R., DeCastro, J., \& Wiseman, R. (2005). Incentive alignment or perverse incentives? A behavioral view of stock options. Management Research, 3(2), 1-17.

Devers, C. E., McNamara, G., Wiseman, R. M., \& Arrfelt, M. (2008). Moving closer to the action: Examining compensation design effects on firm risk. Organization Science, 19(4), 548-566.

Dikova, D., \& van Witteloostuijn, A. (2007). Foreign direct investment mode choice: Entry and establishment modes in transition economies. Journal of International Business Studies, 38, 1013-1033.

DiMaggio, P. J., \& Powell, W. W. (1983). The iron cage revisited: Institutional isomorphism and collective rationality in organizational fields. American Sociological Review, 48(2), 147-160.

Faulconbridge, J., \& Muzio, D. (2016). Global professional service firms and the challenge of institutional complexity: Field relocation as a response strategy. Journal of Management Studies, 53, 89-124.
Gelfand, M. J., Erez, M., \& Aycan, Z. (2007). Cross-cultural organizational behavior. Annual Review of Psychology, 58(1), 479-514.

Gelfand, M. J., Nishii, L. H., \& Raver, J. L. (2006). On the nature and importance of cultural tightness-looseness. Journal of Applied Psychology, 91 (6), 1225-1244.

Gelfand, M. J., Raver, J. L., Nishii, L., Leslie, L. M., Lun, J., Lim, B. C., ... Yamaguchi, S. (2011). Differences between tight and loose cultures: A 33-nation study. Science, 332(6033), 1100-1104

Globerman, S., \& Shapiro, D. (2003). Governance infrastructure and US foreign direct investment. Journal of International Business Studies, 34 (1), 19-39.

Gomez-Mejia, L. R. (1984). Effect of occupation on task related, contextual and job involvement orientation: A cross-cultural perspective. Academy of Management Journal, 27, 706-720.

Gomez-Mejia, L. R. (1988). The role of human resource strategy in export performance: A longitudinal study. Strategic Management Journal, 9(5), 493-505.

Gomez-Mejia, L. R. (1992). Diversification, compensation strategy and firm performance. Strategic Management Journal, 13, 381-397.

Gomez-Mejia, L. R. (1994). Executive compensation: A reassessment and a future research agenda. In G. Ferris (Ed.), Research in personnel and human resource management (Vol. 12, pp. 161-223). Greenwich, CT: JAI Press.

Gomez-Mejia, L. R., Berrone, P., \& Franco-Santos, M. (2010). Compensation and organizational performance. New York, NY: ME Sharpe.

Gomez-Mejia, L. R., Haynes, K. T., Nunez-Nickel, M., Jacobson, K. J. L., \& Moyano-Fuentes, J. (2007). Socioemotional wealth and business risks in family-controlled firms: Evidence from Spanish olive oil mills. Administrative Science Quarterly, 52(1), 106-138.

Gomez-Mejia, L. R., Larraza-Kintana Moyano, J., \& Firfiray, S. (2017). Managerial family ties and employee risk bearing: Evidence from Spanish car dealers. Human Resource Management, 16(3), 439-453.

Gomez-Mejia, L. R., McCann, J. E., \& Page, R. C. (1985). The structure of managerial behaviors and rewards. Industrial Relations, 24, 149-159.

Gomez-Mejia, L. R., Neacsu, I., \& Martin, G. (2019). CEO risk taking and socioemotional wealth: The behavioral agency model, family control and CEO option wealth. Journal of Management, 45(4), 589-618.

Gomez-Mejia, L. R., \& Palich, L. (1997). Cultural diversity and the performance of multinational firms. Journal of International Business Studies, 3, 420-441.

Gomez-Mejia, L. R., Tosi, H., \& Hinkin, T. (1987). Managerial control, performance and executive compensation. Academy of Management Journal, 30, 51-70.

Gomez-Mejia, L. R., \& Welbourne, T. (1991). Compensation strategies in a global context. Human Resource Planning, 14(1), 35-40.

Gomez-Mejia, L. R., Welbourne, T., \& Wiseman, R. (2000). The role of risk sharing and risk taking under gainsharing. Academy of Management Review, 25(3), 492-509.

Gomez-Mejia, L. R., \& Wiseman, R. (2007). Does agency theory have universal relevance? Journal of Organizational Behavior, 8, 81-98.

Gomez-Mejia, L. R., Wiseman, R., \& Johnson, B. (2005). Agency problems in diverse contexts: A global perspective. Journal of Management Studies, 42(7), 1507-1520.

Grossman, W., \& Schoenfeld, L. F. (2001). Resolving ethical dilemmas through international human resource management: $A$ transaction cost economics perspective. Human Resource Management Review, 11(1-2), 55-72.

Guillén, M. F. (2002). Structural inertia, imitation, and foreign expansion: South Korean firms and business groups in China, 1987-95. Academy of Management Journal, 45, 509-525.

Haleblian, J., Devers, C. E., McNamara, G., Carpenter, M. A., \& Davison, R. B. (2009). Taking stock of what we know about mergers 
and acquisitions: A review and research agenda. Journal of Management, 35(3), 469-502.

Hambrick, D. C., \& Fukutomi, G. D. S. (1991). The seasons of a CEO's tenure. Academy of Management Review, 16, 719-742.

Hambrick, D. C., \& Mason, P. A. (1984). Upper echelons: The organization as a reflection of its top managers. Academy of Management Review, 9 (2), 193-206.

Harzing, A. W. (2002). Acquisitions versus greenfield investments: International strategy and management of entry modes. Strategic Management Journal, 23(3), 211-227.

Heckman, J. J. (1979). Sample bias as a specification error. Econometrica, 47(1), 153-162.

Henisz, W. J. (2000). The institutional environment for economic growth. Economics and Politics, 12(1), 1-31.

Hernandez, E., \& Guillén, M. F. (2018). What's theoretically novel about emerging-market multinationals? Journal of International Business Studies, 49(1), 24-33.

Herrmann, P., \& Datta, D. K. (2006). CEO experiences: Effects on the choice of FDI entry mode. Journal of Management Studies, 43(4), 755-778.

Hofstede, G. (1980). Culture's consequences: International differences in work-related values. Beverly Hills, CA: Sage.

Holm, A. E., Decreton, B., Nell, P. C., \& Klopf, P. (2017). The dynamic response process to conflicting institutional demands in MNC subsidiaries: An inductive study in the sub-Saharan African e-commerce sector. Global Strategy Journal, 7(1), 104-124.

Holmstrom, B. (1979). Moral hazard and observability. Bell Journal of Economics, 10, 74-91.

Hou, W., Li, S., \& Priem, R. L. (2013). How do CEOs matter? The moderating effects of CEO compensation and tenure on equity ownership in international joint ventures. Journal of International Management, 19(2), 138-151.

Isidor, R., Schwens, C., \& Kabst, R. (2011). Human resource management and early internationalization: Is there a leap-frogging in international staffing? International Journal of Human Resource Management, 22(10), 2167-2184.

Jaw, Y. L., \& Lin, W. T. (2009). Corporate elite characteristics and firm's internationalization: CEO-level and TMT-level roles. International Journal of Human Resource Management, 20(1), 220-233.

Kahneman, D., \& Tversky, A. (1979). Prospect theory: An analysis of decisions and risk. Econometrica, 47(2), 262-291.

Kaufmann, D., Kraay, A., \& Mastruzzi, M. (2010). The worldwide governance indicators: Methodology and analytical issues. World Bank Policy Research Working Paper No. 5430. Washington, DC: World Bank.

Khan, Z., Rao-Nicholson, R., Akhtar, P., \& He, S. (in press). Cross-border mergers and acquisitions of emerging economies' multinational enterprises-The mediating role of socialization integration mechanisms for successful integration. Human Resource Management Review. https://doi.org/10.1016/j.hrmr.2016.12.003

Kogut, B., \& Singh, H. (1988). The effect of national culture on the choice of entry mode. Journal of International Business Studies, 19, 411-432.

Kostova, T., Roth, K., \& Dacin, M. T. (2008). Institutional theory in the study of multinational corporations: A critique and new directions. Academy of Management Review, 33, 994-1006.

Koyuncu, B., Hamori, M., \& Baruch, Y. (2017). Guest editor's introduction: CEOs' career: Emerging trends and future directions. Human Resource Management, 56(2), 195-203.

Kunisch, S., Menz, M., \& Cannella, A. A., Jr. (2019). The CEO as a key microfoundation of global strategy: Task demands, CEO origin, and the CEO's international background. Global Strategy Journal, 9(1), 19-41.

Larraza-Kintana, M., Wiseman, R. M., Gomez-Mejia, L. R., \& Welbourne, T. M. (2007). Disentangling compensation and employment risks using behavioral agency model. Strategic Management Journal, 28, 1001-1019.
Le, S., \& Kroll, M. (2017). CEO international experience: Effects on strategic change and firm performance. Journal of International Business Studies, 48(5), 573-595.

Leung, K., \& Morris, M. W. (2015). Values, schemas, and norms in the culture-behavior nexus: A situated dynamics framework. Journal of International Business Studies, 46(9), 1028-1050.

Levy, O. (2005). The influence of top management team attention patterns of global strategic posture of firms. Journal of Organizational Behavior, 26(7), 797-819

Lu, J. W. (2002). Intra- and inter-organizational imitative behavior: Institutional influences on Japanese firms' entry mode choice. Journal of International Business Studies, 33, 19-37.

Martin, G., Wiseman, R., \& Gomez-Mejia, L. R. (2016). Bridging finance and behavioral scholarship on agent risk sharing and risk taking. Academy of Management Perspectives, 30(4), 349-368.

Martin, G. P., Gomez-Mejia, L. R., \& Wiseman, R. M. (2013). Executive stock options as mixed gambles: Revisiting the behavioral agency model. Academy of Management Journal, 56, 451-472.

Martin, G. P., Washburn, N., Makri, M., \& Gomez-Mejia, L. R. (2015). Not all risk taking is born equal: The behavioral agency model and CEO's perception of firm efficacy. Human Resource Management, 54(3), 483-498.

McNamara, G. M., Haleblian, J., \& Dykes, B. J. (2008). The performance implications of participating in an acquisition wave: Early mover advantages, bandwagon effects, and the moderating influence of industry characteristics and acquirer tactics. Academy of Management Journal, 51, 113-130.

Merriman, K. K., \& Deckop, J. R. (2007). Loss aversion and variable pay: A motivational perspective. International Journal of Human Resource Management, 18(6), 1026-1041.

Meyer, J. W., \& Rowan, B. (1977). Institutionalized organizations: Formal structure as myth and ceremony. American Journal of Sociology, 88, 340-363.

Miller, J., Hom, P. W., \& Gomez-Mejia, L. R. (2001). The high cost of low wages: Does Maquiladora compensation strategy reduce turnover? Journal of International Business Studies, 32(3), 585-595.

Miller, J. S., Wiseman, R. M., \& Gomez-Mejia, L. R. (2002). The fit between CEO compensation design and firm risk. Academy of Management Journal, 45, 745-756.

Musteen, M., Datta, D. K., \& Herrmann, P. (2009). Ownership structure and CEO compensation: Implications for the choice of foreign market entry modes. Journal of International Business Studies, 40, 321-338.

Nyberg, A. J., Fulmer, I. S., Gerhart, B., \& Carpenter, M. A. (2010). Agency theory revisited: CEO return and shareholder interest alignment. Academy of Management Journal, 53(5), 1029-1049.

Oliver, C. (1991). Strategic responses to institutional processes. Academy of Management Review, 16, 145-179.

Palich, L. E., \& Gomez-Mejia, L. R. (1999). A theory of global straegy and firm efficiencies: Considering the effects of cultural diversity. Journal of Management, 25(4), 587-606.

Papke, L. E., \& Wooldridge, J. M. (2008). Panel data methods for fractional response variables with an application to test pass rates. Journal of Econometrics, 145, 121-133.

Patel, P. C., Li, M., Triana, M.d. C., \& Park, H. D. (2018). Pay dispersion among the top management team and outside directors: Its impact on firm risk and firm performance. Human Resource Management, 57(1), 177-192.

Pelto, P. J. (1968). The differences between "tight" and "loose" societies. Transactions, 5(5), 37-40.

Powell, K. S., \& Rhee, M. (2016). Experience in different institutional environments and foreign subsidiary ownership structure. Journal of Management, 42(6), 1434-1461. 
Rathert, N. (2016). Strategies of legitimation: MNEs and the adoption of CSR in response to host-country institutions. Journal of International Business Studies, 47(7), 858-879.

Regner, P., \& Edman, J. (2014). MNE institutional advantage: How subunits shape, transpose and evade host country institutions. Journal of International Business Studies, 45, 275-302.

Reusen, E., \& Stouthuysen, K. (2017). Misaligned control: The role of management control system imitation in supply chains. Accounting, Organizations, and Society, 61, 22-35.

Rhodes-Kropf, M., Robinson, D. T., \& Viswanathan, S. (2005). Valuation waves and merger activity: The empirical evidence. Journal of Financial Economics, 77(3), 561-603.

Rich, J. T., \& Bush, L. V. (1987). Executive stock ownership after the acquisition. Human Resource Management, 26(4), 503-512.

Rugman, A. M., \& Verbeke, A. (2004). A perspective on regional and global strategies of multinational enterprises. Journal of International Business Studies, 35(1), 3-18.

Salomon, R., \& Wu, Z. (2012). Institutional distance and local isomorphism strategy. Journal of International Business Studies, 43(4), 343-367.

Sanders, W. M. G., \& Carpenter, M. A. (1998). Internationalization and firm governance: The roles of CEO compensation, top team composition, and board structure. Academy of Management Journal, 41(2), 158-178.

Sanders, W. M. G., \& Hambrick, D. C. (2007). Swinging for the fences: The effects of CEO stock options on company risk taking and performance. Academy of Management Journal, 50(5), 1055-1078.

Seo, J. (2017). Board effectiveness and CEO pay: Board information processing capacity, monitoring complexity, and CEO pay-forperformance sensitivity. Human Resource Management, 56(3), 373-388.

Shavell, S. (1979). On moral hazard and insurance. Quarterly Journal of Economics, 93, 541-562.

Shaver, M. J. (1998). Accounting for endogeneity when assessing strategy performance: Does entry mode choice affect FDI survival? Management Science, 44(4), 433-594.

Slangen, A. H. L. (2013). Greenfield or acquisition entry? The roles of policy uncertainty and MNE legitimacy in host countries. Global Strategy Journal, 3, 262-280.

Slangen, A. H. L., \& Hennart, J. F. (2007). Greenfield or acquisition entry: A review of the empirical foreign establishment mode literature. Journal of International Management, 13(4), 403-429.

Slangen, A. H. L., \& van Tulder, R. J. M. (2009). Cultural distance, political risk, or governance quality? Towards a more accurate conceptualization and measurement of external uncertainty in foreign entry mode research. International Business Review, 18, 276-291.

Su, Y., Fan, D., \& Rao-Nicholson, R. (2017). Internationalization of Chinese banking and financial institutions: A fuzzy-set analysis of the leaderTMT dynamics. International Journal of Human Resource Management, 30(14), 2137-2165.

Suchman, M. C. (1995). Managing legitimacy: Strategic and institutional approaches. Academy of Management Review, 20, 571-610.

Sung, S. Y., Choi, J. N., \& Kang, S. C. (2017). Incentive pay and firm performance: Moderating roles of procedural justice climate and environmental turbulence. Human Resource Management, 56(2), 287-305.

Tihanyi, L., Griffith, D. A., \& Russell, C. J. (2005). The effect of cultural distance on entry mode choice, international diversification, and MNE performance: A meta-analysis. Journal of International Business Studies, 36(3), 270-283.

Toh, S. M., \& Leonardelli, G. J. (2012). Cultural constraints on the emergence of women as leaders. Journal of World Business, 47(4), 604-611.

Tosi, H. L., \& Gomez-Mejia, L. R. (1989). The decoupling of performance and CEO pay: An agency theory perspective. Administrative Science Quarterly, 39, 1002-1016.
Trevino, L., Gomez-Mejia, L. R., \& Balkin, D. B. (2018). Meritocracies or masculinities? The differential allocation of named professorships by gender in the academy. Journal of Management, 44(3), 972-1000.

Tsui, L. S., \& Moellering, G. (2010). Wary managers: Unfavorable environments, perceived vulnerability, and the development of trust in foreign enterprises in China. Journal of International Business Studies, 41(6), 1016-1035.

United Nations Conference on Trade and Development. (2018). Foreign direct investment. Retrieved from http://unctad.org/en/Pages/DIAE/ Foreign-Direct-Investment-(FDI).aspx

Waguespack, D. M., Dunford, E. T., \& Birnir, J. K. (2018). Cultural imprinting, institutions, and the organization of new firms. Strategy Science, 3 (2), 367-480.

Wang, G., Holmes, R. M., Oh, I. S., \& Zhu, W. (2016). Do CEOs matter to firm strategic actions and firm performance? A meta-analytic investigation based on upper echelons theory. Personnel Psychology, 69(4), 775-862.

Wang, G., \& Singh, P. (2014). The evolution of CEO compensation over the organizational life cycle: A contingency explanation. Human Resource Management Review, 24(2), 144-159.

Werner, S., \& Ward, S. G. (2004). Recent compensation research: An eclectic review. Human Resource Management Review, 14(2), 201-227.

Westney, D. E. (1993). Institutionalization theory and the multinational corporations. In S. Ghoshal \& D. E. Westney (Eds.), Organization theory and the multinational corporation (pp. 53-76). New York, NY: St Martin's Press.

Westphal, J. D., Gulati, R., \& Shortell, S. M. (1997). Customization or conformity? An institutional and network perspective on the content and consequences of TQM adoption. Administrative Science Quarterly, 42, 366-394.

Wiseman, R. M., Cuevas-Rodriguez, G., \& Gomez-Mejia, L. R. (2012). Towards a social theory of agency. Journal of Management Studies, 49 (1), 202-222.

Wiseman, R. M., \& Gomez-Mejia, L. R. (1998). A behavioral agency model of managerial risk taking. Academy of Management Review, 23(1), 133-153.

Woo, H. (2019). The effect of CEO compensation structure on the early internationalization of newly public firms. International Journal of Human Resource Management, 30(12), 1977-1996.

Wowak, A., Gomez-Mejia, L. R., \& Steinbach, A. (2017). Inducements and motives of the CEO: A holistic perspective on the drivers of executive behaviour. Academy of Management Annals, 11(2), 669-702.

Xia, J., Tan, J., \& Tan, D. (2008). Mimetic entry and bandwagon effect: The rise and decline of international equity joint venture in China. Strategic Management Journal, 29, 195-217.

Yahiaoui, D., Chebbi, H., \& Weber, Y. (2016). HR practices, context and knowledge transfer in M\&A. International Journal of Human Resource Management, 27(20), 2415-2435.

Yiu, D., \& Makino, S. (2002). The choice between joint venture and wholly owned subsidiary: An institutional perspective. Organization Science, 13(6), 601-740.

Zhao, H., Luo, Y., \& Suh, T. (2004). Transaction cost determinants and ownership-based entry mode choice: A meta-analytical review. Journal of International Business Studies, 35, 524-544.

Zimmerman, M. A., \& Zeitz, G. J. (2002). Beyond survival: Achieving new venture growth by building legitimacy. Academy of Management Review, 27, 414-431.

Zolotoy, L., O'Sullivan, D., Martin, G. P., \& Veeraraghavan, M. (2018). The role of affect in shaping the behavioral consequences of CEO option incentives. Journal of Management, 45(7), 2920-2951.

Zucker, L. G. (1977). The role of institutionalization in cultural persistence. American Sociological Review, 42, 726-743. 


\section{AUTHOR BIOGRAPHIES}

Mirko Benischke is an Associate Professor of Global Strategy at the Rotterdam School of Management, Erasmus University (The Netherlands). He earned his PhD from the University of Auckland in New Zealand. His research lies at the intersection of international business, strategic management, and corporate governance and has been published in the Strategic Management Journal, Journal of International Business Studies, Journal of World Business, and the Academy of Management Perspectives.

Geoffrey P. Martin is a Professor of Strategy at the Melbourne Business School, University of Melbourne (Australia). He earned his PhD from IE Business School in Madrid. His research focuses on executive compensation, strategic decision making and agency problems. He has been published in the Strategic Management Journal, Academy of Management Journal, Journal of Management, Journal of Business Ethics and Harvard Business Review.

Luis R. Gomez-Mejia is Regents University Professor of Management and holder of the Weatherup/Overby Chair at W.P. Carey School of Business, Arizona State University. Dr Gomez-Mejia has published over 270 articles appearing in the most prestigious management journals, including the Academy of Management Journal, Academy of Management Review, Administrative Science Quarterly, Strategic Management Journal, Journal of International Business Studies, Journal of Management, Journal of Management
Studies, and Personnel Psychology. Professor Gomez-Mejia was an elected member of the Board of Governors of the Academy of Management and served as President of the Personnel/Human Resources Division of the Academy of Management (with approximately 2,500 members). He was also president (during 1997-2007) and founder of the Iberoamerican Academy of Management (an affiliate of the Academy of Management), which covers Spain/Portugal, all of Latin America, as well as Hispanic faculty in U.S. universities.

Grigorij Ljubownikow is a Lecturer of Strategy at the Graduate School of Management, University of Auckland. He earned his PhD from the University of Auckland. At the intersection of strategic management and organizational theory, his research focuses on how competition in general and competitive interdependencies in particular influence competitive behaviors such as acquisitions and alliances.

How to cite this article: Benischke MHMartin GP, GomezMejia LR, Ljubownikow G. The effect of CEO incentives on deviations from institutional norms in foreign market expansion decisions: Behavioral agency and cross-border acquisitions. Hum Resour Manage. 2020;1-20. https://doi.org/ 10.1002/hrm.22006 